\title{
James Webb Space Telescope Optical Telescope Element Mirror Development History and Results
}

\author{
Lee D. Feinberg, Mark Clampin, Ritva Keski-Kuha \\ NASA Goddard Space Flight Center, Greenbelt Maryland 20771 \\ Charlie Atkinson, Scott Texter \\ Northrop Grumman Aerospace Systems, Redondo Beach, California \\ Mark Bergeland, Benjamin B. Gallagher \\ Ball Aerospace \& Technologies Corp., 1600 Commerce Street, Boulder, CO 80301, USA
}

\begin{abstract}
In a little under a decade, the James Webb Space Telescope (JWST) program has designed, manufactured, assembled and tested 21 flight beryllium mirrors for the James Webb Space Telescope Optical Telescope Element. This paper will summarize the mirror development history starting with the selection of beryllium as the mirror material and ending with the final test results. It will provide an overview of the technological roadmap and schedules and the key challenges that were overcome. It will also provide a summary of the key tests that were performed and the results of these tests.
\end{abstract}

Key words: James Webb Space Telescope, Mirrors, Optical Telescope Element, OTE

\section{INTRODUCTION}

The James Webb Space Telescope (JWST) Optical Telescope Element includes 21 light-weighted, cryogenic beryllium primary mirror segments. ${ }^{1}$ The full set includes eighteen $1.52 \mathrm{~m}$ point to point hexagonal primary mirror segments along with a Secondary Mirror (SM), Tertiary Mirror (TM) and Fine Steering Mirror (FSM). The mirrors for JWST required a technology development program, a competitive mirror selection process, a facilitization effort, an aggressive risk management program, a full scale production effort, and a thorough test program. As this effort is now complete, all of the JWST mirrors are finished and available to the program.

\section{TECHNOLOGY DEVELOPMENT}

The technology development process for JWST started with the recognition that the cryogenic mirror technology used on the Spitzer Space Telescope was not sufficient for JWST. In fact, as shown in Figure 1 , the JWST program identified the need for and began development of lower areal density mirrors soon after the 1996 inception of the program. While several mirror technology development paths were followed during those very early days, the most important ones were the Subscale Beryllium Mirror Demonstrator (SBMD), the Advanced Mirror Systems Demonstrator (AMSD) and the NGST Mirror System Demonstrator (NMSD). ${ }^{2}$ The SBMD and $\mathrm{AMSD}^{3}$ programs ultimately provided the key technology pathway for JWST while NMSD helped educate the program on options that were not pursued. The various mirror architectures and specifications developed in the three programs are shown on the top of Figure 2. The SBMD was a Ball Aerospace Internal Research And Development (IRAD) effort to make a .5 meter highly lightweighted berrylium mirror (sphere) using the new isotropic 0-30 Beryllium powder developed by Brush Wellman. Soon thereafter, a multi-agency collaboration between NASA, DoD and NRO was formed to develop $15 \mathrm{~kg} / \mathrm{m} 2$ lightweight mirrors. In its initial phase, the 
program selected the 8 architectures shown on the left of Figure 2 for study. Three of the mirror architectures were down-selected for Phase 2 AMSD efforts to actually fabricate the $1.2 \mathrm{~m}$ flat to flat $15 \mathrm{Kg} / \mathrm{m} 2$ mirrors studied in Phase 1 . Of the three architectures, a Ball Beryllium mirror, a Hughes Danbury High Authority Mirror, and a Kodak (now ITT Exelis) ULE mirror, the Ball and Kodak mirrors were continued and finished after the JWST prime contractor was selectẹ.

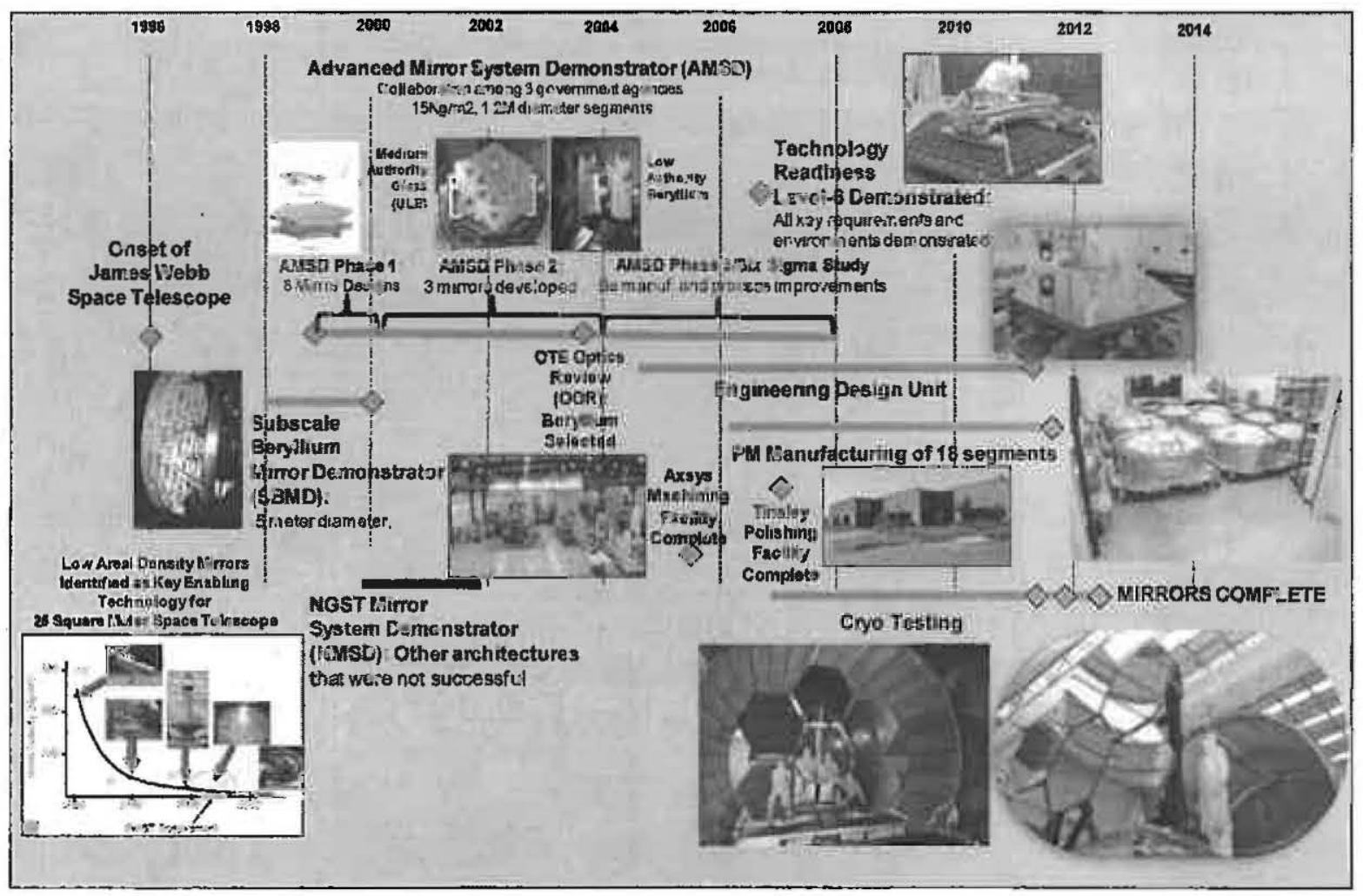

Figure 1. Roadmap

While the SBMD and AMSD programs were very instructive and achieved much of the technology demonstration needed, achieving full Technology Readiness Level- 6 (TRL-6) ${ }^{4}$ was a requirement by the program Technology NonAdvocate Review and AMSD and SBMD did not sufficiently demonstrate both flight survivability (acoustics and vibe) and stress issues of fabrication. Therefore, as shown in the lower right of Figure 2, the stress demonstration and flight survivability efforts were added to the program to achieve TRL-6. This included adding an AMSD Phase 3 which involved demonstrating the control of beryllium fabrication stresses via stress coupons. In addition, the demonstration of mirror acoustics and vibration survival was done with a partially finished flight mirror (using an electronic speckle pattern interferometer for pre and post optical measurements) and the demonstration of the actuation was done using the Engineering Design Unit. As will be shown later, many of the technology items were funded through the JWST risk management and mitigation process. 


\begin{tabular}{|c|c|c|c|}
\hline \multicolumn{4}{|c|}{ Wide Variety of Mirror System Design Parameters Studled } \\
\hline Item & SBMD (Bail) & NMSD & AMSD \\
\hline $\begin{array}{l}\text { Substrate } \\
\text { Material }\end{array}$ & $\mathrm{Be}$ & $\begin{array}{l}\text { Glass/Compo } \\
\text { site Hybrid } \\
\text { (COI) } \\
\text { Gla ss (UA) }\end{array}$ & $\begin{array}{l}\text { Be(Bail) } \\
\text { ULE (Kodak) } \\
\text { SiO2 } \\
\text { (Goodrich) }\end{array}$ \\
\hline $\begin{array}{l}\text { Reaction } \\
\text { Structure }\end{array}$ & $\mathrm{Be}$ & $\begin{array}{l}\text { Composite } \\
\text { (both) }\end{array}$ & $\begin{array}{l}\text { Composite } \\
\text { (all) }\end{array}$ \\
\hline $\begin{array}{l}\text { Control } \\
\text { Authority }\end{array}$ & $\begin{array}{l}\text { Low (Focus } \\
\text { Only) }\end{array}$ & $\begin{array}{l}\text { Low (COI) } \\
\text { High (UA) }\end{array}$ & $\begin{array}{l}\text { Low (BaII) } \\
\text { Medium } \\
\text { (Kodak) } \\
\text { High } \\
\text { (Goodrich) }\end{array}$ \\
\hline Mounting & $\begin{array}{l}\text { Linear } \\
\text { Flexure }\end{array}$ & $\begin{array}{l}\text { Bipods (COI) } \\
166 \text { Hard } \\
\text { (UA) }\end{array}$ & $\begin{array}{l}\text { 9 Bi-Flex } \\
\text { (BaII) } \\
\text { 16 Force } \\
\text { (Kodak) } \\
\text { 67 BVAx- } \\
\text { Flex } \\
\text { (Goodrich) }\end{array}$ \\
\hline Diameter & $\begin{array}{c}0.53 \mathrm{~m} \\
.\end{array}$ & $\begin{array}{l}2 \mathrm{~m}(\mathrm{COI}) \\
1.6 \mathrm{~m}(\mathrm{UA})\end{array}$ & $\begin{array}{l}1.38 \mathrm{~m} \text { (BaIl) } \\
1.4 \mathrm{~m} \\
\text { (Kodak) } \\
1.3 \mathrm{~m} \\
\text { (Goodrich) }\end{array}$ \\
\hline Areal Density & $\begin{array}{l}9.8 \mathrm{~kg} / \mathrm{m} 2 \\
\text { (mirror only) }\end{array}$ & $13 \mathrm{~kg} / \mathrm{m} 2$ & $15 \mathrm{~kg} / \mathrm{m} 2$ \\
\hline
\end{tabular}

\begin{tabular}{|l|c|c|c|l|}
\hline \multicolumn{5}{|c|}{ Mirror Technology Development Specifica tions } \\
\hline Item & $\begin{array}{c}\text { SBMD } \\
\text { Circle with } \\
\text { Flat }\end{array}$ & NMSD & AMSD & Units \\
\hline Prescription & Sphere & Sphere & $\begin{array}{c}\text { Off-Axis } \\
\text { Para bola }\end{array}$ & \\
\hline Diameter & $>0.5$ & 1.5 to 2.0 & 1.2 to 1.5 & meter \\
\hline $\begin{array}{l}\text { Areal } \\
\text { Density }\end{array}$ & $<12$ & $<15$ & $<15$ & $\mathrm{~kg} / \mathrm{m}^{2}$ \\
\hline Radius & 20 & 15 & 10 & meter \\
\hline PV Figure & 160 & 160 & 250 & $\mathrm{~nm}$ \\
\hline RMS Figure & - & $\cdots$ & 50 & $\mathrm{~nm}$ \\
\hline $\begin{array}{l}\text { PV Mid (1- } \\
\text { 10cm }\end{array}$ & 63 & 63 & $-\cdots$ & $\mathrm{nm}$ \\
\hline RMS Finish & 3 & 2 & 4 & $\mathrm{~nm}$ \\
\hline $\begin{array}{l}\text { Stiffness (1" } \\
\text { Mode) }\end{array}$ & - & - & 150 & $\mathrm{HZ}$ \\
\hline
\end{tabular}

\begin{tabular}{|c|c|c|}
\hline Demonstrator & Tochnology & Validilty to JWST \\
\hline SBMD & 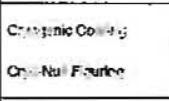 & 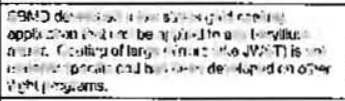 \\
\hline AMSD Mirror & 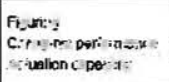 & 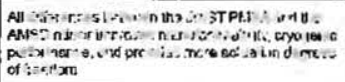 \\
\hline $\begin{array}{l}\text { AMSD Stress } \\
\text { Coupons }\end{array}$ & $\begin{array}{l}\text { Long lerm nate: } \\
\text { staw thy }\end{array}$ & 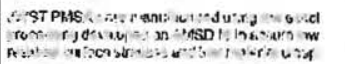 \\
\hline $\begin{array}{l}\text { JWST EDU \& } \\
\text { Flight Segment }\end{array}$ & 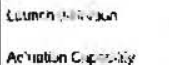 & 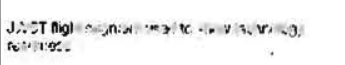 \\
\hline
\end{tabular}

Figure 2: Mirror Technologies Summary

\section{MIRROR SELECTION}

Once the prime contractor was brought on board, a Mirror Recommendation Board consisting of experts from both the prime contractor team and the government worked collaboratively to select the mirror architecture. Many of these experts carried over from the technology phase. The team evaluated the two mirror options that the prime contractor proposed, one that used Beryllium and one that used ULE. The key data used to assess the cryogenic performance was the cryogenic test results of the AMSD-2 data. The decision process and dates and the team involved in this activity are shown in Figure $4 .^{5}$

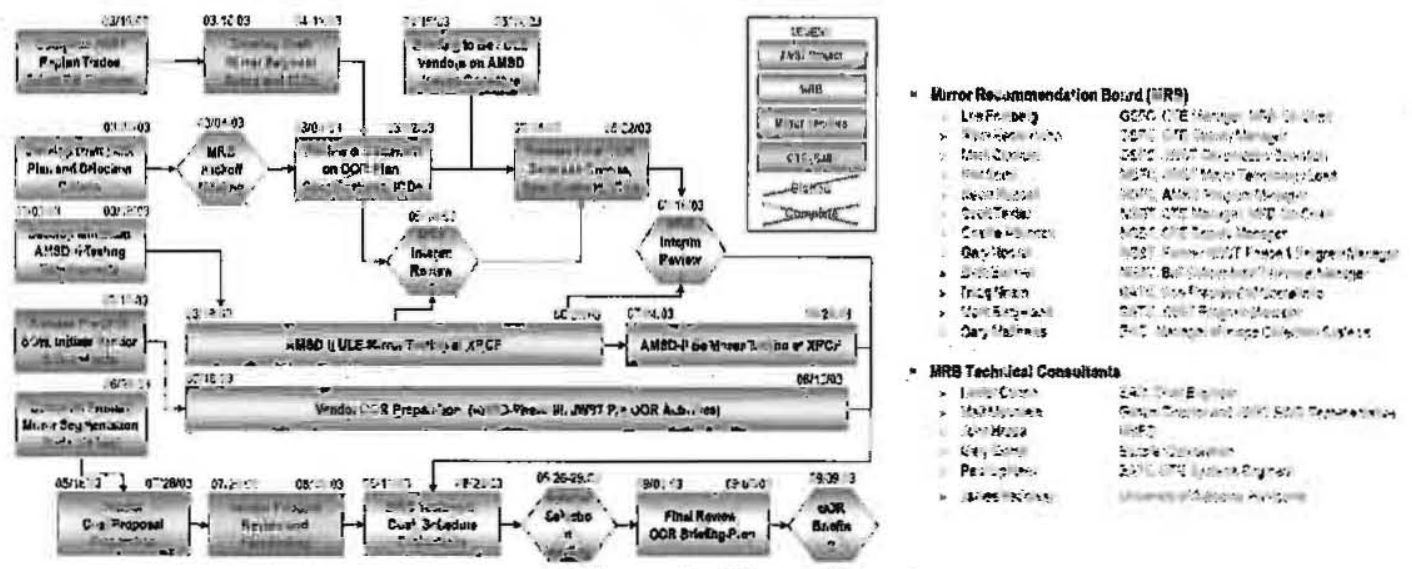

Figure 4: Mirror Selection 
The results of the AMSD-2 cryogenic testing results for the ULE and Beryllium mirror are shown in Figure 5. The results substantiated the key technical advantage of Beryllium: its thermal conductivity and CTE at cryogenic temperatures. In the end, Beryllium was selected on this technical basis which was perceived to hold system advantages (for example, active thermal control was not needed). Beryllium also had another system advantage in that it could be lighter weight for the architectures proposed. The AMSD-2 data was the primary factor in the mirror selection and the main data used to plan the fabrication efforts.

\section{$\sim 30 \mathrm{~K}$ minus Ambient}

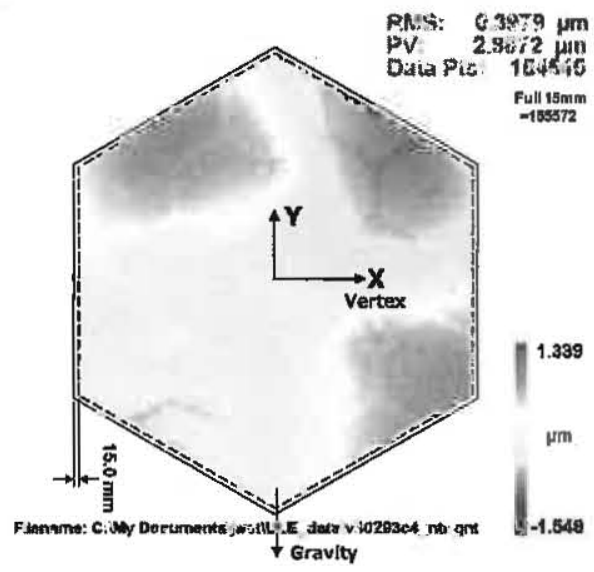

ULE

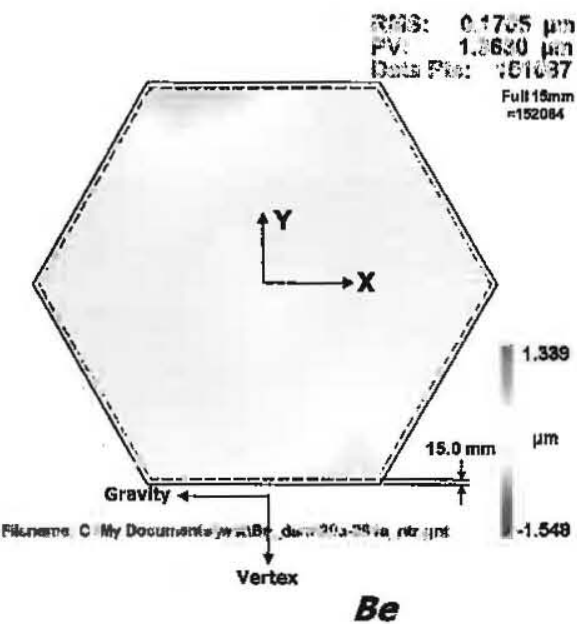

$B e$

Beryllium Mirror Selected Because of Superior Cryogenic Properties

Figure 5: AMSD-2 Cryogenic Data

\section{RISK MANAGEMENT}

Even before the mirror was selected, JWST initiated risk management processes to mitigate risks associated with its development. ${ }^{6}$ In many ways the early adoption of risk management and the early prioritization of mirror risk management funding helped lead to the success of the mirror program. As can be seen in Figure 6, many risks were identified, entered and mitigated through the life of the mirror development program. The risks themselves chronologically track the phase of the program in which they were entered. For example, early in the program the key risks were early fabrication (especially beryllium stress issues) and design issues (for example, large vibroacoustics loads). As the mirror development progressed, the risks transitioned to specific fabrication issues (eg, edges), testing and spares. As a result of the risk process, an engineering design unit was added for both the primary mirror segment and the secondary and both were extremely valuable and later converted to spares. 


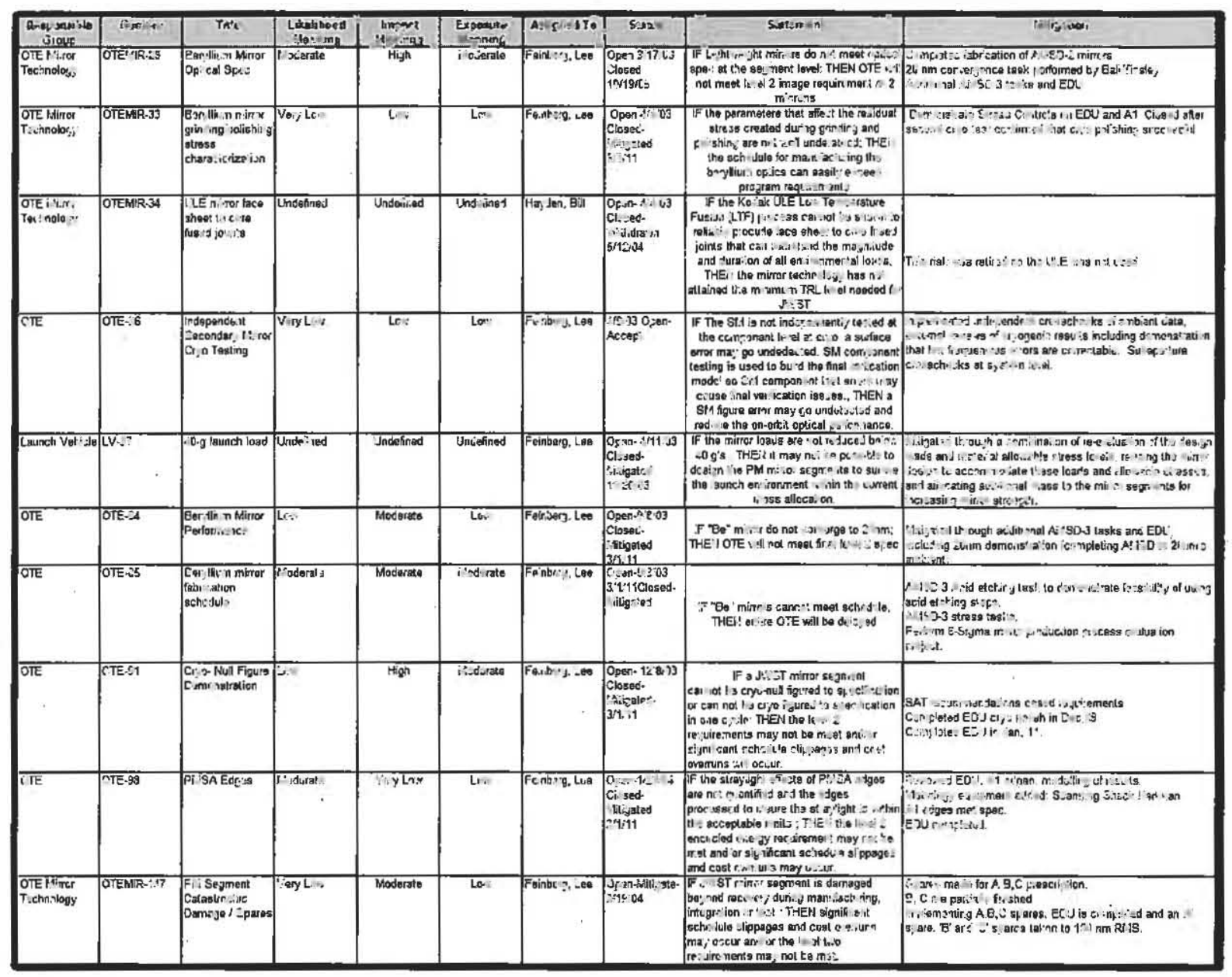

Figure 6: Mirror Risk History

\section{MIRROR FABRICATION}

The mirror fabrication involved a large effort that was managed by Ball Aerospace and which included several contractors and facilities around the county. The basic flow and typical durations of the fabrication effort is shown below in Figure 7. 


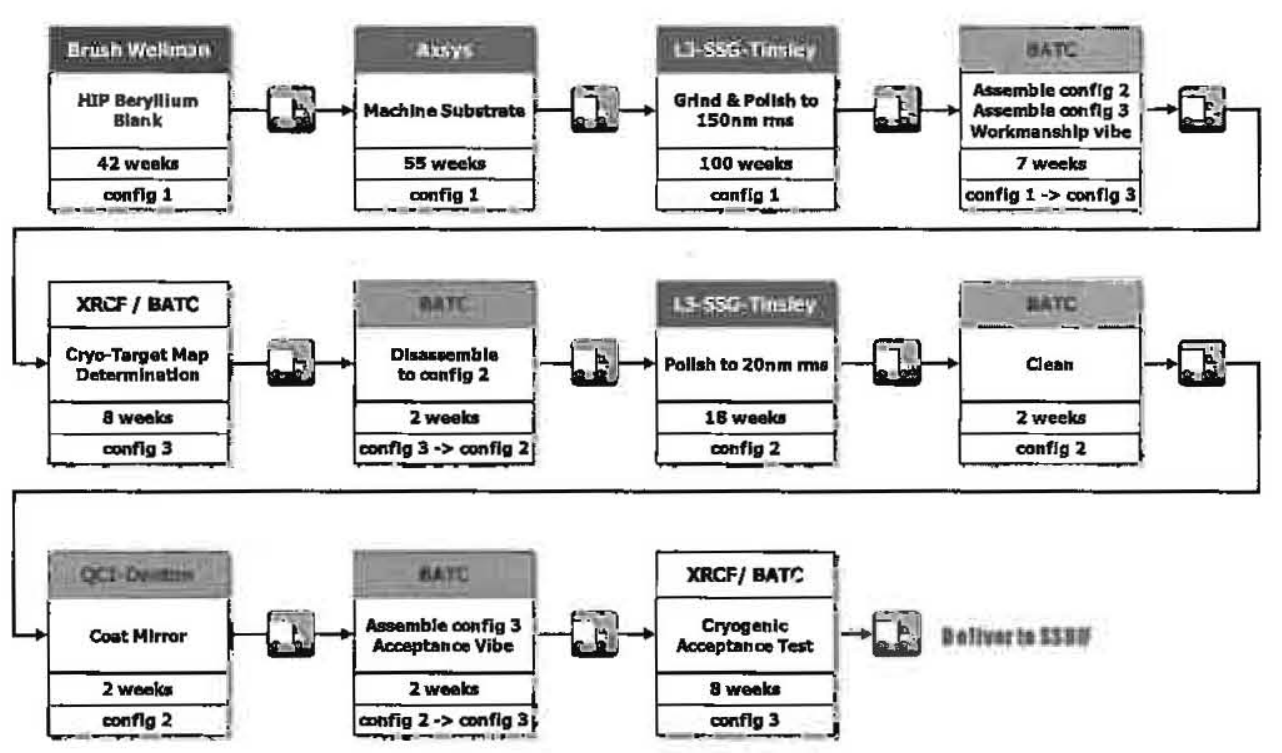

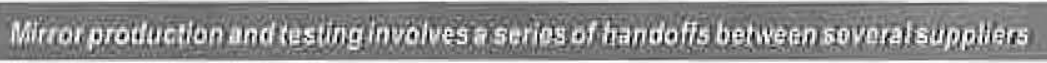

Figure 7: Mirror Fabrication Flow

The actual as-run schedule for the entire mirror fabrication effort can be seen below in Figure 8. The end to end effort lasted approximately 8.5 years.

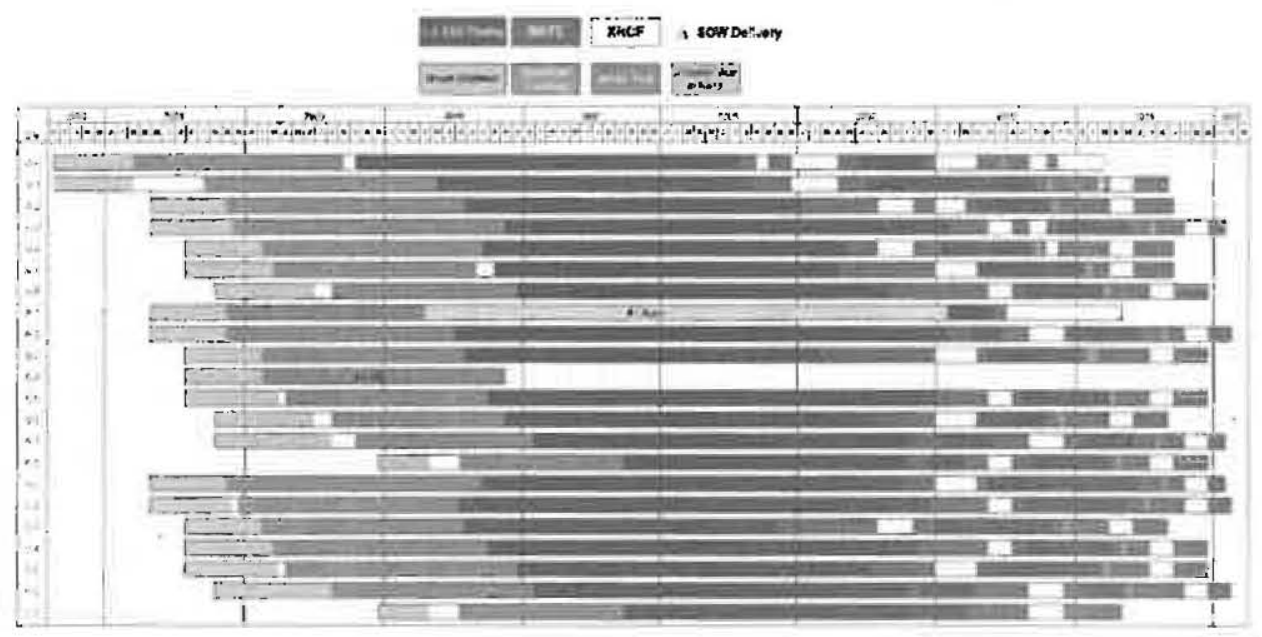

Figure 8: Mirror As-run Schedule

\section{RESULTS}

The fabrication of all flight mirrors including coating and testing completed in December, 2011. The mirror themselves can be seen in Figure 9. The top level RMS results for each of the mirrors can be seen in Figure 10. All mirrors meet their RMS specification which is the critical driver for telescope performance. More detailed results for the primary mirror segments can be seen after ambient testing in Figure 11. More detailed final cryogenic 
testing results can be seen in Figures 12 and 13. Although there were a few segment level allocations not met, the primary mirror requirements overall were met with margin.

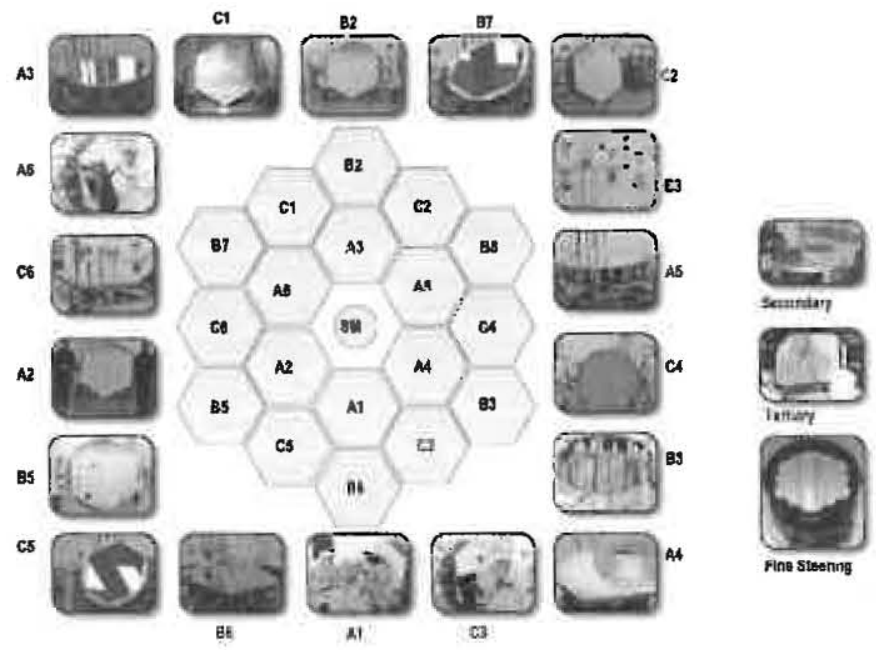

Figure 9; Flight Mirrors

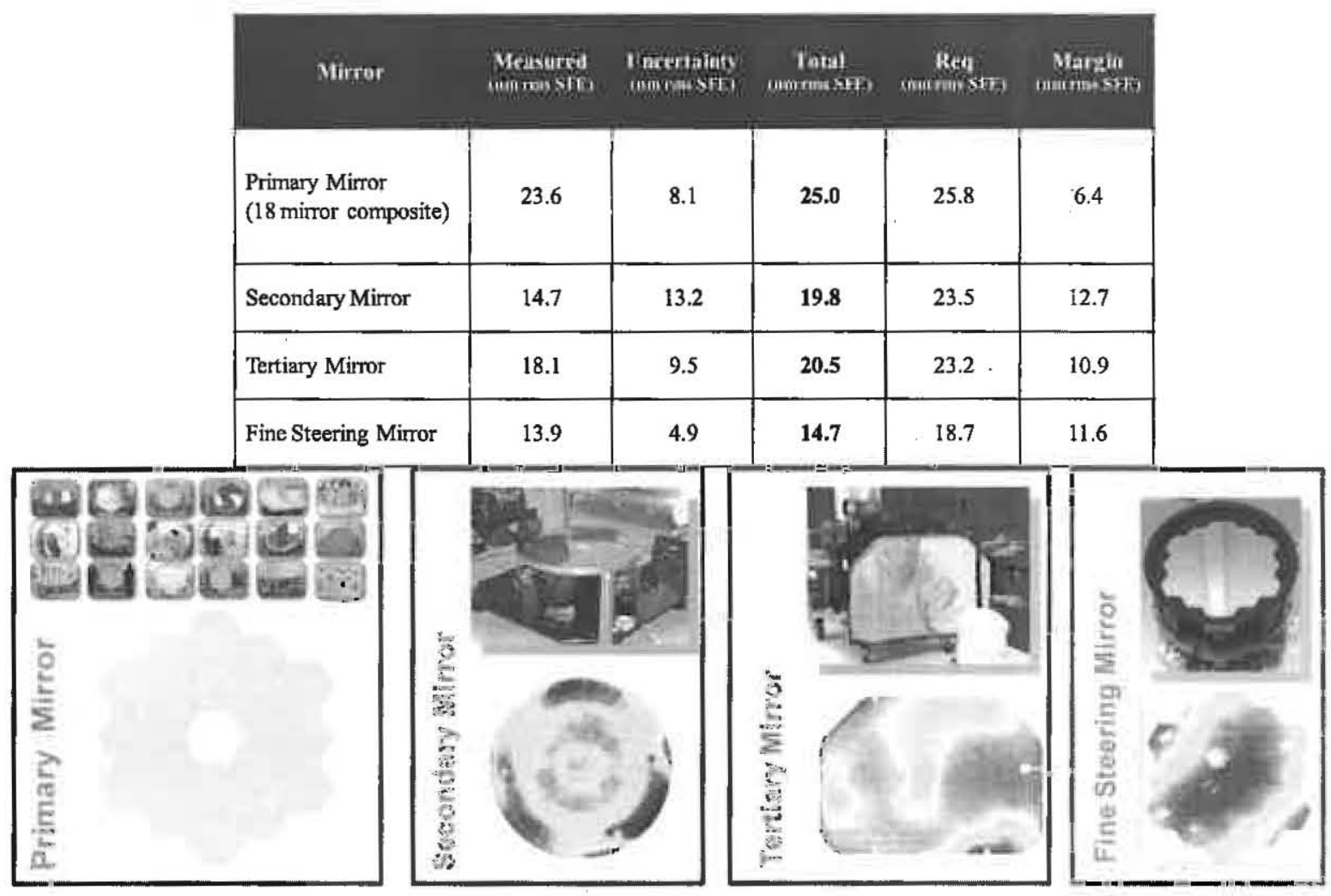

Figure 10: Flight Mirror Top-level Performance 


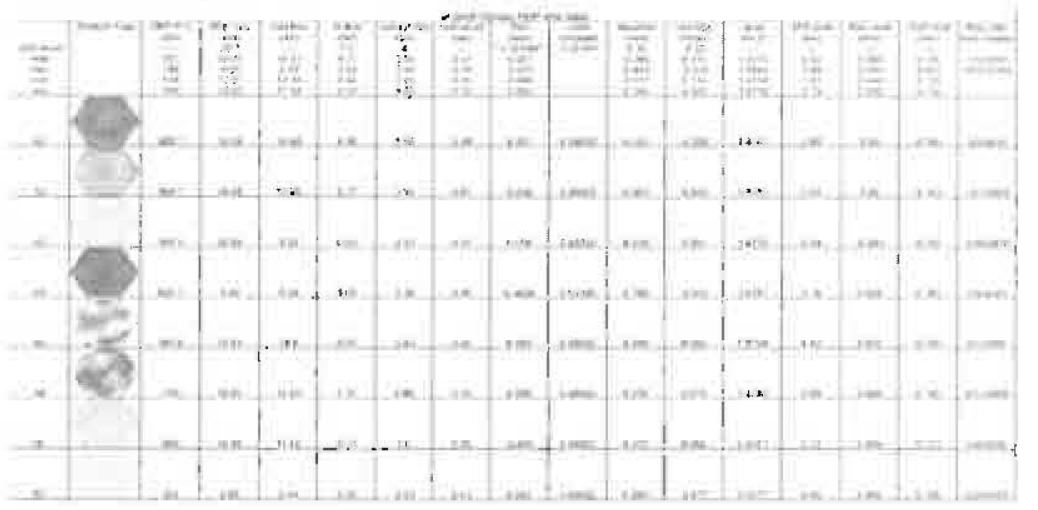

Figure 11: Primary Mirror Segment Performance after Polishing

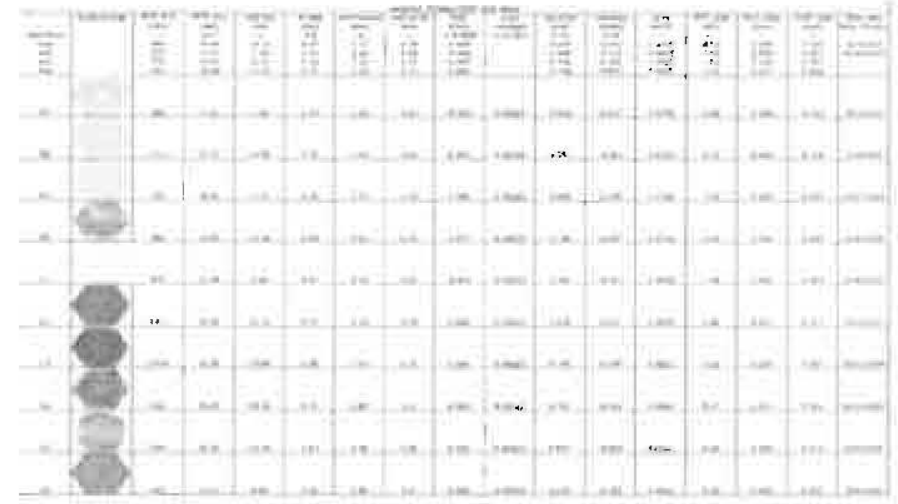

Figure 12: Primary Mirror Segment Performance after Polishing

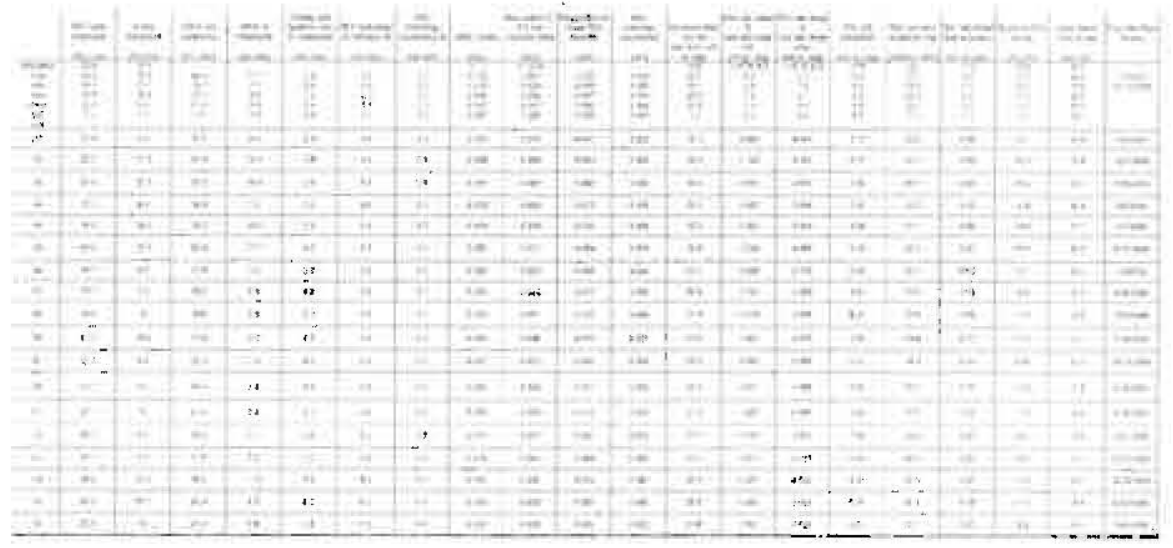

Figure 13: Primary Mirror Segment Cryogenic Performance

\section{SUMMARY}

The development of the mirrors for JWST was a major undertaking. The team involved included engineers, managers and technicians from several companies and organizations, many of whom are shown on Figure 14. In under a decade, 21 flight mirrors including the $>25$ square meters of lightweighted, cryogenic beryllium mirrors were designed and fabricated. While the original technology 
effort benefitted from a collaboration between NASA and other government agencies, the development effort was primarily a collaboration between NASA, industry and academia. The mirrors meet their top level specification and many technical challenges were overcome. The focus now is on finishing the rest of the telescope and performing system level testing

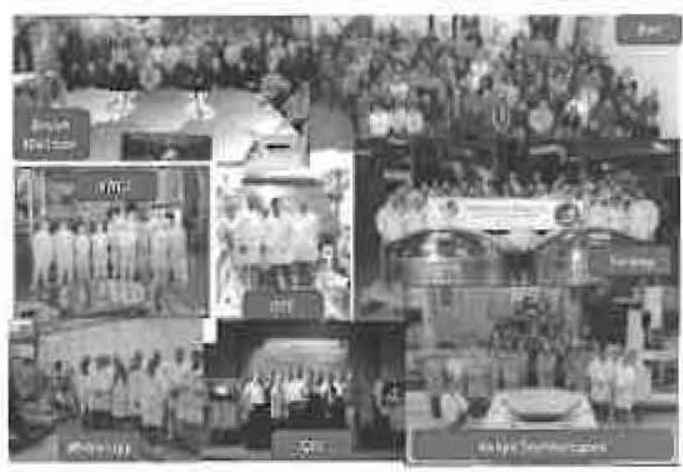

Figure 14: Mirror Teams

\section{ACKNOWLEDGEMENTS}

The authors would like to thank the hundreds of engineers, technicians and scientists around the country who helped make the mirror production a success. The list of names is too numerous to include but includes Brush Wellman, Axsys Technologies, L3-Communications SSG-Tinsley, Ball Aerospace, QCl, NGAS, SAO, MSFC, GSFC, StScI, CDA, ATK, 4D Technologies, and Wavefront Sciences .. With respect to this particular paper, the authors would like to thank Paul Lightsey for providing the tabulated mirror performance data and Ratna Sengupta for the risk data. The authors would also like to call out Lester Cohen of SAO, James Hadaway of UAH and Bob Brown, Dave Chaney and Koby Smith of Ball Aerospace for their major contributions to the success. The authors would like to thank Phil Sabelhaus, John Decker and Martin Mohan for the vision to prioritize funding of the JWST mirrors early in the program.

\section{REFERENCES}

${ }^{1}$ L. D Feinberg, "James Webb Space Telescope Optical Telescope Element Development Status”, p. 814-817, 5487-30, SPIE Proceedings, Glasgow, June 2004

${ }^{2}$ S.E. Kendrick, R.J. Brown, S. Streetman, D. Chaney, et al, "Lightweighted Beryllium Cryogenic Mirrors for Both Monolithic and Segmented Space Telescopes", p. 241-253, 4850-40, SPIE Proceedings, Waikoloa, August, 2002

${ }^{3}$ P. J. Reardon, J.B Hadaway, et al, “Advanced Mirror Demonstrator Cryogenic Test Error Budget”, p. 221-229, Vol. 4850-47, SPIE Proceedings, Waikoloa, August, 2002

${ }^{4}$ H. P. Stahl, "JWST Lightweight Mirror TRL-6 Results", IEEE Aerospace, 2007

${ }^{5}$ H. P. Stahl, L. D. Feinberg, S.C. Texter , "Primary Mirror Material Selection", p. 818-824, 5487-31, SPIE Proceedings, Glasgow, June 2004

${ }^{6}$ Knowledge Management Challenges for Successful Space Missions with Lessons from the James Webb Space Telescope (JWST), IAC Conference, 2007 


\section{James Webb Space Telescope Optical Telescope Element Mirror Development History and Results}

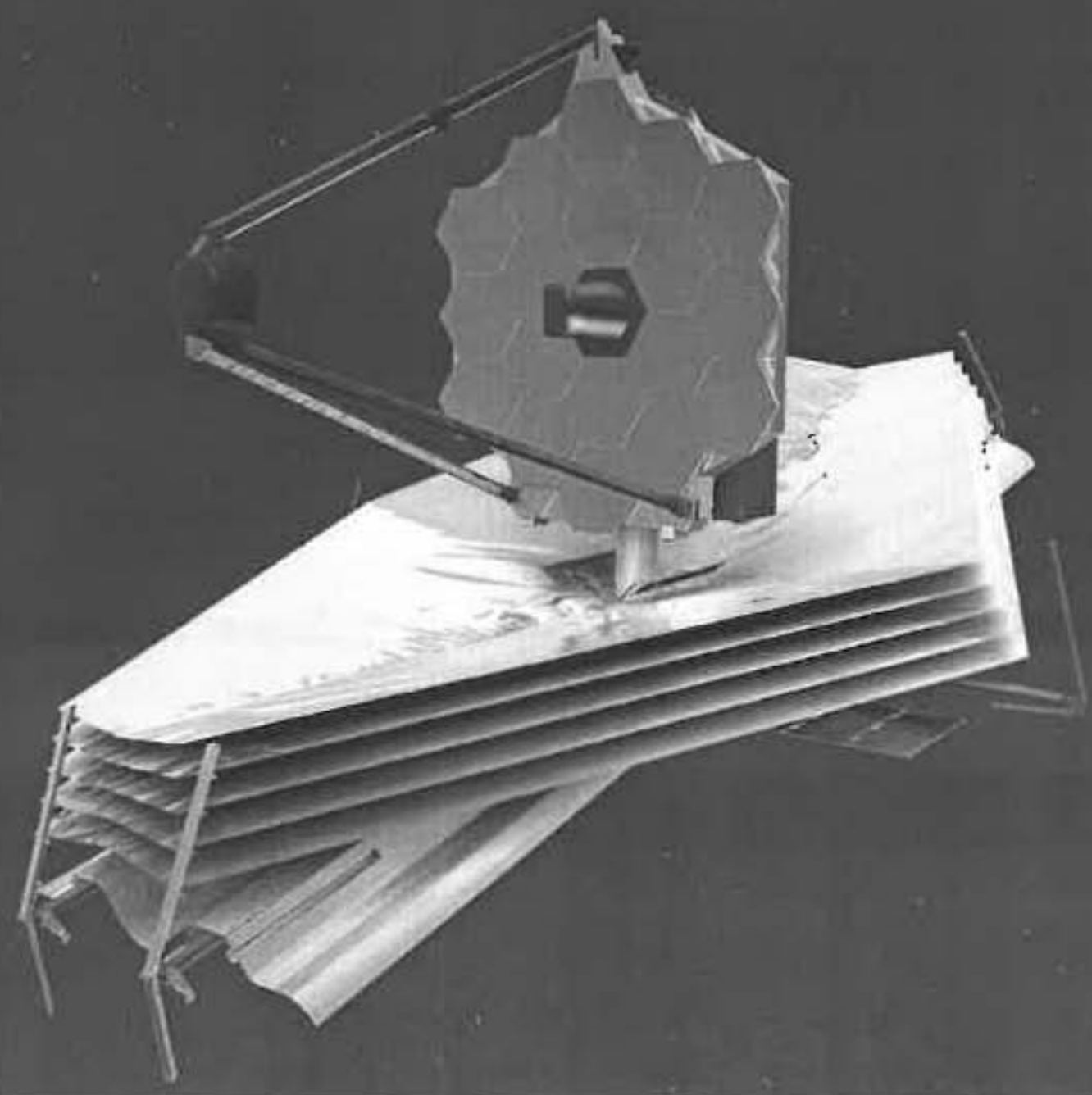

Lee Feinberg Ritva Keski Kuha, GSFC

Scott Texter, NGAS Charlie Atkinson, NGAS Mark Bergeland, Ball Aerospace Ben Gallagher, Ball Aerospace 


\section{Outline}

- Introduction

- Overall roadmap

- Technology development

- Mirror Selection/00R Results and Findings

- Risk Management History

- Team - MST

- Results

- Tinsley

- Final 


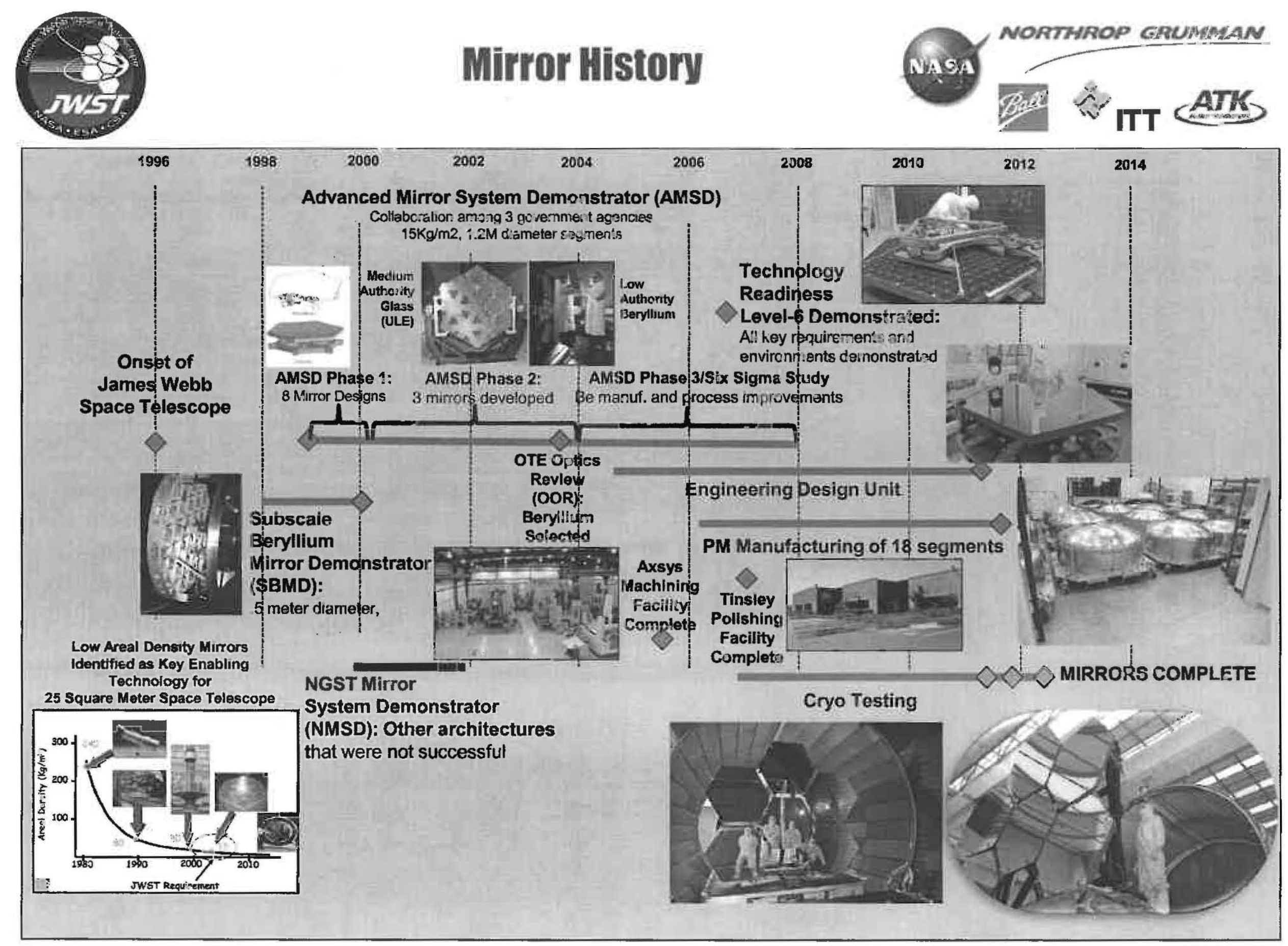




\section{Technology Development History}

\begin{tabular}{|c|c|c|c|}
\hline \multicolumn{4}{|c|}{ Wide Variety of Mirror System Design Parameters Studied } \\
\hline Item & SBMD (Bail) & NMSD & AMSD \\
\hline $\begin{array}{l}\text { Substrate } \\
\text { Material }\end{array}$ & $\mathrm{Be}$ & $\begin{array}{l}\text { Glass/Compo } \\
\text { site Hybrid } \\
\text { (COI) } \\
\text { Glass (UA) }\end{array}$ & $\begin{array}{l}\text { Be (Ball) } \\
\text { ULE (Kodak) } \\
\text { SiO2 } \\
\text { (Goodrich) }\end{array}$ \\
\hline $\begin{array}{l}\text { Reaction } \\
\text { Structure }\end{array}$ & $\mathrm{Be}$ & $\begin{array}{l}\text { Composite } \\
\text { (both) }\end{array}$ & $\begin{array}{l}\text { Composite } \\
\text { (all) }\end{array}$ \\
\hline $\begin{array}{l}\text { Control } \\
\text { Authority }\end{array}$ & $\begin{array}{l}\text { Low (Focus } \\
\text { Only) }\end{array}$ & $\begin{array}{l}\text { Low (COI) } \\
\text { High (UA) }\end{array}$ & $\begin{array}{l}\text { Low (Ball) } \\
\text { Medium } \\
\text { (Kodak) } \\
\text { High } \\
\text { (Goodrich) }\end{array}$ \\
\hline Mounting & $\begin{array}{l}\text { Linear } \\
\text { Flexure }\end{array}$ & $\begin{array}{l}\text { Bipods (COI) } \\
166 \text { Hard } \\
\text { (UA) }\end{array}$ & $\begin{array}{l}9 \text { Bi-Flex } \\
\text { (Ball) } \\
16 \text { Force } \\
\text { (Kodak) } \\
67 \mathrm{Bi} / \mathrm{Ax}- \\
\text { Flex } \\
\text { (Goodrich) } \\
\end{array}$ \\
\hline Diameter & $0.53 \mathrm{~m}$ & $\begin{array}{l}2 \mathrm{~m}(\mathrm{COI}) \\
1.6 \mathrm{~m}(\mathrm{UA})\end{array}$ & $\begin{array}{l}1.38 \mathrm{~m} \text { (Ball) } \\
1.4 \mathrm{~m} \\
\text { (Kodak) } \\
1.3 \mathrm{~m} \\
\text { (Goodrich) }\end{array}$ \\
\hline Areal Density & $\begin{array}{l}9.8 \mathrm{~kg} / \mathrm{m} 2 \\
\text { (mirror only) }\end{array}$ & $13 \mathrm{~kg} / \mathrm{m} 2$ & $15 \mathrm{~kg} / \mathrm{m} 2$ \\
\hline
\end{tabular}

\begin{tabular}{|c|c|c|c|c|c|}
\hline \multicolumn{6}{|c|}{ Mirror Technology Development Specifications } \\
\hline Item & SBMD & & MSD & AMSD & Units \\
\hline Form & $\begin{array}{l}\text { Circle with } \\
\text { Flat }\end{array}$ & & Hex & Hex & \\
\hline Prescription & Sphere & & phere & $\begin{array}{l}\text { Off-Axis } \\
\text { Parabola }\end{array}$ & \\
\hline Diameter & $>0.5$ & & 5 to 2.0 & 1.2 to 1.5 & meter \\
\hline $\begin{array}{l}\text { Areal } \\
\text { Density }\end{array}$ & $<12$ & & $<15$ & $<15$ & $\mathrm{~kg} / \mathrm{m}^{2}$ \\
\hline Radius & 20 & & 15 & 10 & meter \\
\hline PV Figure & 160 & & 160 & 250 & $\mathrm{~nm}$ \\
\hline RMS Figure & $\ldots$ & & -- & 50 & $\mathrm{~nm}$ \\
\hline $\begin{array}{l}\text { PV Mid (1- } \\
\left.10 \mathrm{~cm}^{-1}\right)\end{array}$ & 63 & & 63 & -- & $\mathrm{nm}$ \\
\hline RMS Finish & 3 & & 2 & 4 & $\mathrm{~nm}$ \\
\hline $\begin{array}{l}\text { Stiffness }\left(1^{\text {st }}\right. \\
\text { Mode) }\end{array}$ & -- & & - & 150 & $\mathrm{HZ}$ \\
\hline Demonstrator & \multicolumn{2}{|c|}{ Technology } & \multicolumn{3}{|c|}{ Validity to JWST } \\
\hline SBMD & \multicolumn{2}{|c|}{$\begin{array}{l}\mathrm{Cr}, \mathrm{c} \text { jenic Cozing } \\
\text { Cryo-Nul Figuring }\end{array}$} & \multicolumn{3}{|c|}{ 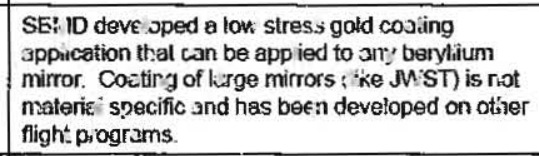 } \\
\hline AMSD Mirror & \multicolumn{2}{|c|}{$\begin{array}{l}\text { Fiquing } \\
\text { Cryogenic per jumancs } \\
\text { Actuition coperits }\end{array}$} & \multicolumn{3}{|c|}{ 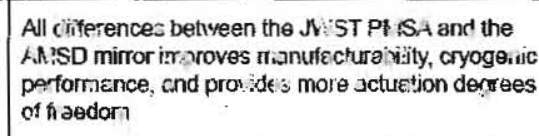 } \\
\hline $\begin{array}{l}\text { AMSD Stress } \\
\text { Coupons }\end{array}$ & \multicolumn{2}{|c|}{$\begin{array}{l}\text { Long term materia } \\
\text { stability: }\end{array}$} & \multicolumn{3}{|c|}{ 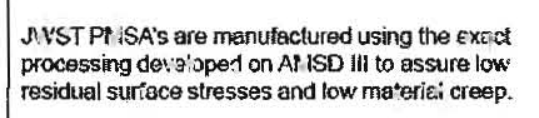 } \\
\hline $\begin{array}{l}\text { JWVST EDU \& } \\
\text { Flight Segment }\end{array}$ & \multicolumn{2}{|c|}{$\begin{array}{l}\text { Launch distoriton } \\
\text { Actuation Corobility }\end{array}$} & \multicolumn{3}{|c|}{$\begin{array}{l}\text { Jit'sT fight segment ust d t shoiv technoiogy } \\
\text { readiness }\end{array}$} \\
\hline
\end{tabular}




\section{Incremental TRL-6}

\begin{tabular}{|c|c|c|}
\hline Demonstrator & Technology & Validity to JWST \\
\hline SBMD & $\begin{array}{l}\text { Cryogenic Coating } \\
\text { Cryo-Nuil Figuring }\end{array}$ & $\begin{array}{l}\text { SENID developed a low stress gold coating } \\
\text { application that can be appiled to any beryltium } \\
\text { mirror. Coating of large mirrors (like JWST) is not } \\
\text { material sperific and has been developed on other } \\
\text { flight prograns. }\end{array}$ \\
\hline AMSD Mirror & $\begin{array}{l}\text { Figuring } \\
\text { Eryogenis performance } \\
\text { Actuation capability }\end{array}$ & $\begin{array}{l}\text { All differences between the JWST PliSA and the } \\
\text { ABISD mirror improves marufacturability. cryogenic } \\
\text { perfomance, and provides more actuation degrees } \\
\text { of fresdom }\end{array}$ \\
\hline $\begin{array}{l}\text { AMSD Stress } \\
\text { Coupons }\end{array}$ & $\begin{array}{l}\text { Long term material } \\
\text { stability }\end{array}$ & $\begin{array}{l}\text { JWST FMSA's are manufactured using the exact } \\
\text { processing developed on AMSD Ill to assure low } \\
\text { residual surface stresses and liww material creep. }\end{array}$ \\
\hline $\begin{array}{l}\text { JWST EDU \& } \\
\text { Flight Segment }\end{array}$ & $\begin{array}{l}\text { Launch djetortion } \\
\text { Actuation Capability }\end{array}$ & $\begin{array}{l}\text { WST flight segment used to show technology } \\
\text { readiness }\end{array}$ \\
\hline
\end{tabular}


- NASA, DOD, NRO \$50M partnership funded 3 lightweight mirror technologies shown on the right

- Ball beryllium mirror technology completed and baselined for JWST in 2003

- Ball beryllium mirror demonstrated all key aspects of JWST technology except for demonstration of vibroacoustics survival which will be demonstrated this June on the Engineering Design Unit mirror

- Mirror manufacturing of flight mirrors started in September 2003

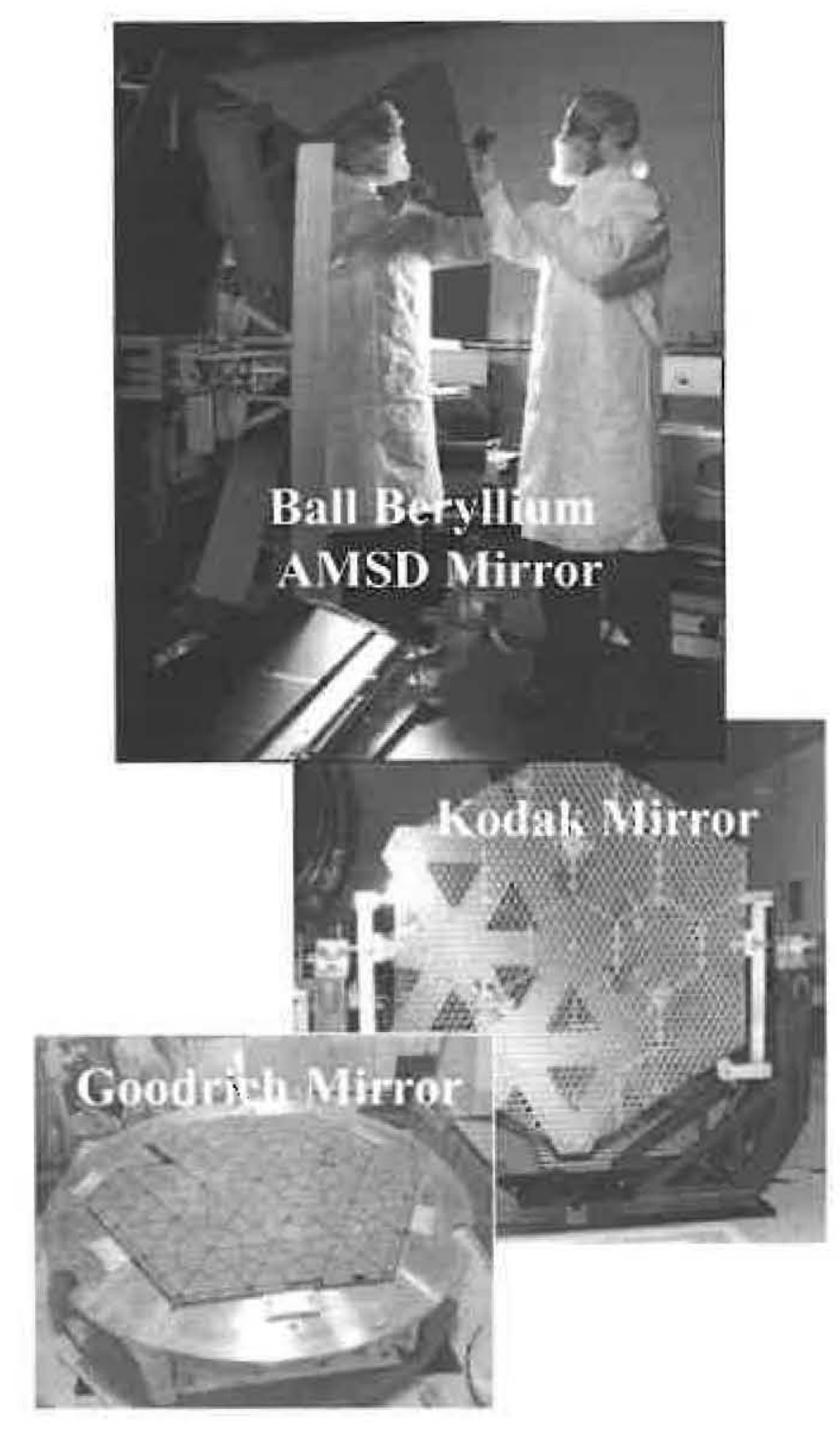




\section{Mirror Technology Choices}

\section{K minus Ambient}

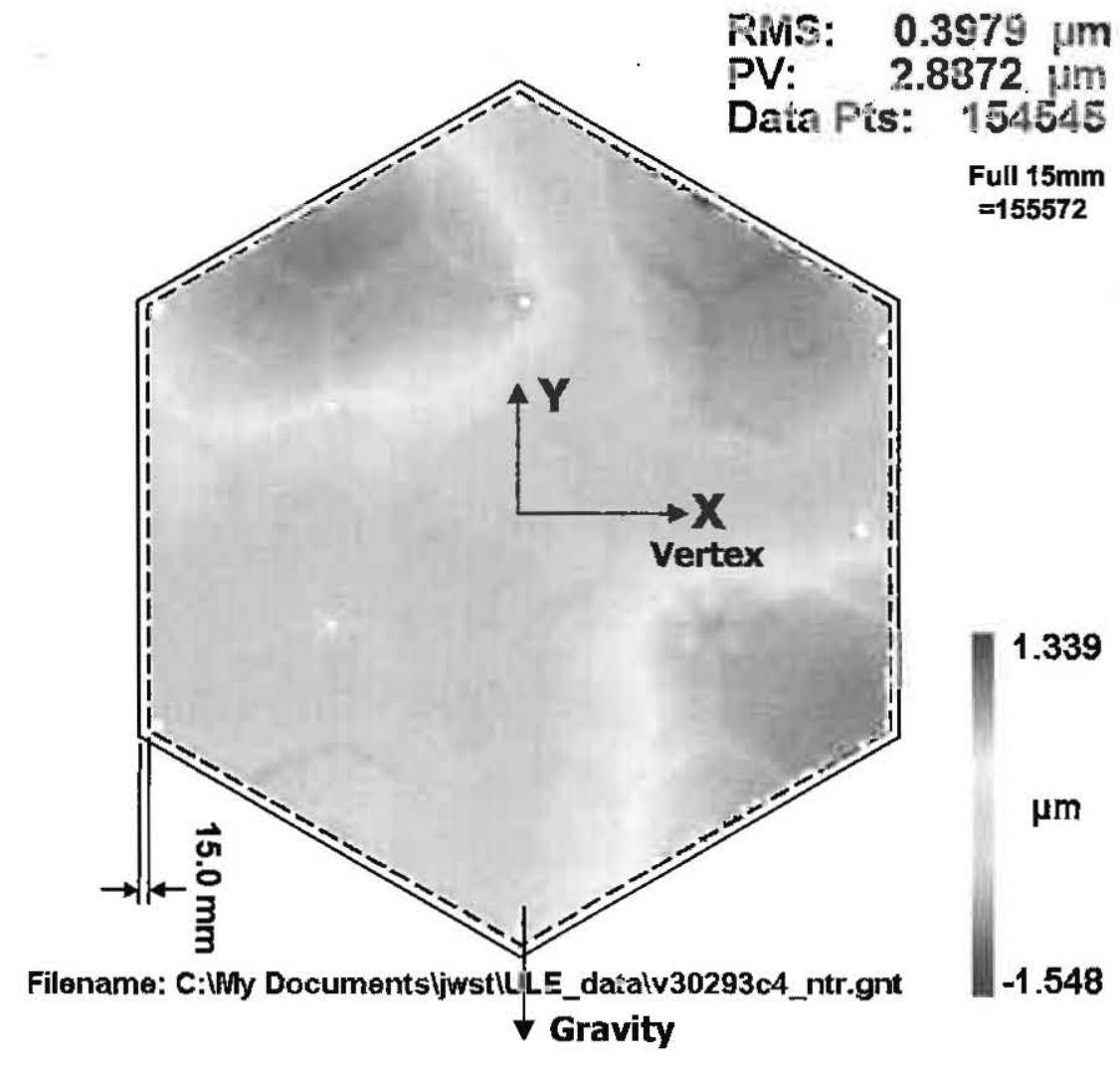

ULE

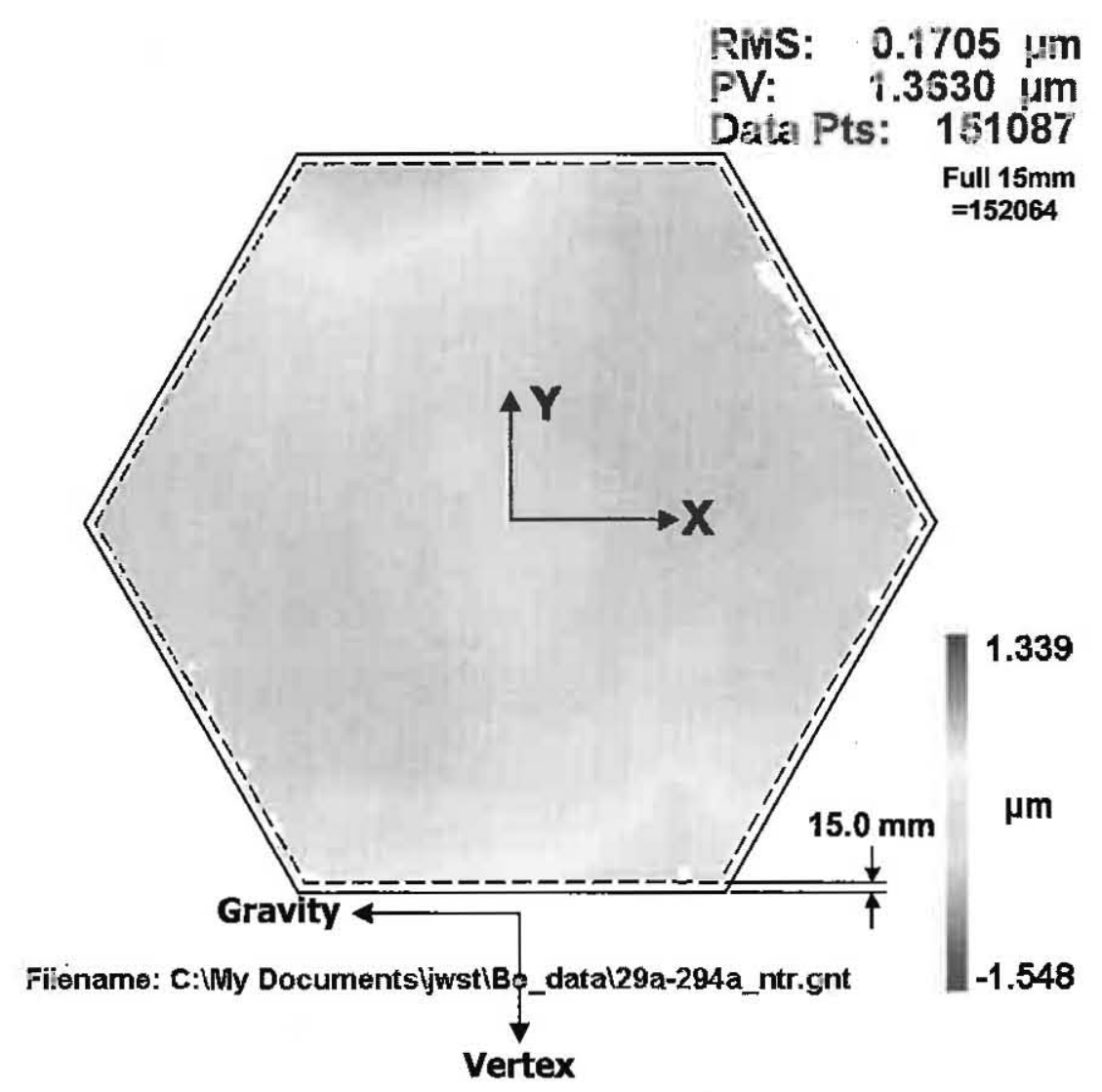

Be

Beryllium Mirror Had Superior Cryogenic Properties 


\section{Mirror Selection Process and Results}

- Beryllium was rated as the highest performing, lowest technical risk solution

- Material has superior cryo CTE and conductivity, only technical issue was managing surface stresses to achieve final convergences

- Provided best potential science performance, had significant margins on thermal performance and stiffness/mass

- Key concerns were schedule and staffing at Tinsley

- Material and manufacturing cost deltas between ULE and Beryllium were small when compared to the potential schedule deltas

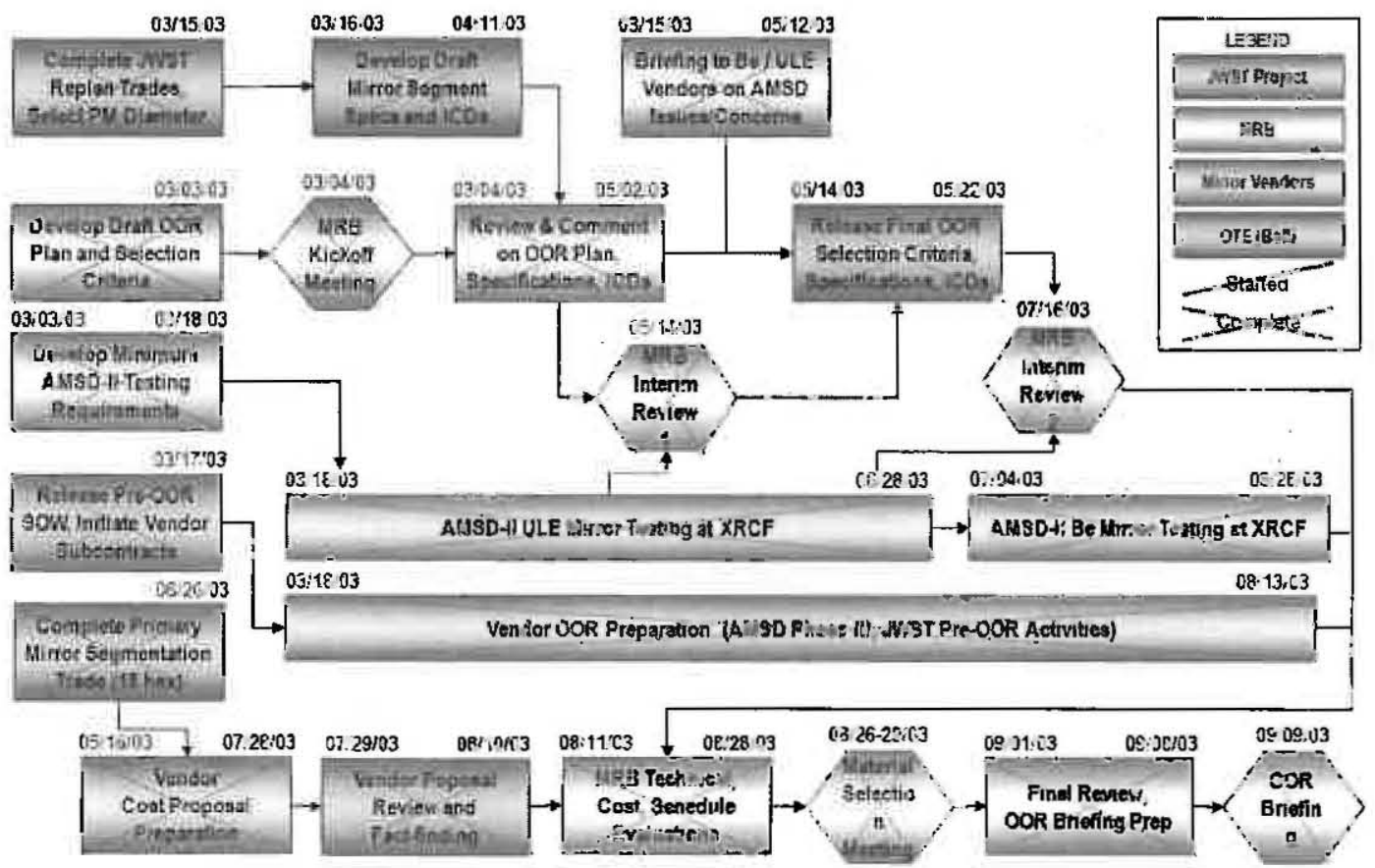

Mirror Recommendation Board (MRB)

- Lee Fenberg GSFC, OTE Manager, MRB CO-Chair

Ritva Keski-Kuha GSFC, OTE Deputy Manager

- Mark Campin GSFC, JWST Observatory Scientist:

2 Ph! Stahl

- KevinRussell

MSFC, JWST Mirror Technology Lead

> ScottTexter

> Char'eAtkinson NGST, OTE Deputy Menager I.SSFC, AMSD Program Manager - Garj Rosiak NGST, =ormer NGST Phase 1 Program Manager

Beth Baine:

- Doug Neam

- Mark Eergeian NGST, Ba. Subcontract Technicz' Manager

- Gary :lathews

BATC, Vice Presiden of Operations

BATC, JWST Program : Ylanage

EKC, Stanager of Image Cciection S; stems

- MRB Technical Consultants

- LesterCchen

- Matt Wountain

- John Hraba

SAO, Chief Engineer

- Gary Go!n:

Gemi i i Jrector and JWST SWG Representaf've

- Pav'Lightsey

Schafer Corporatic.1

BATC, OTE Systems Engineer

Uiversity of A abama, Huntsi ille 


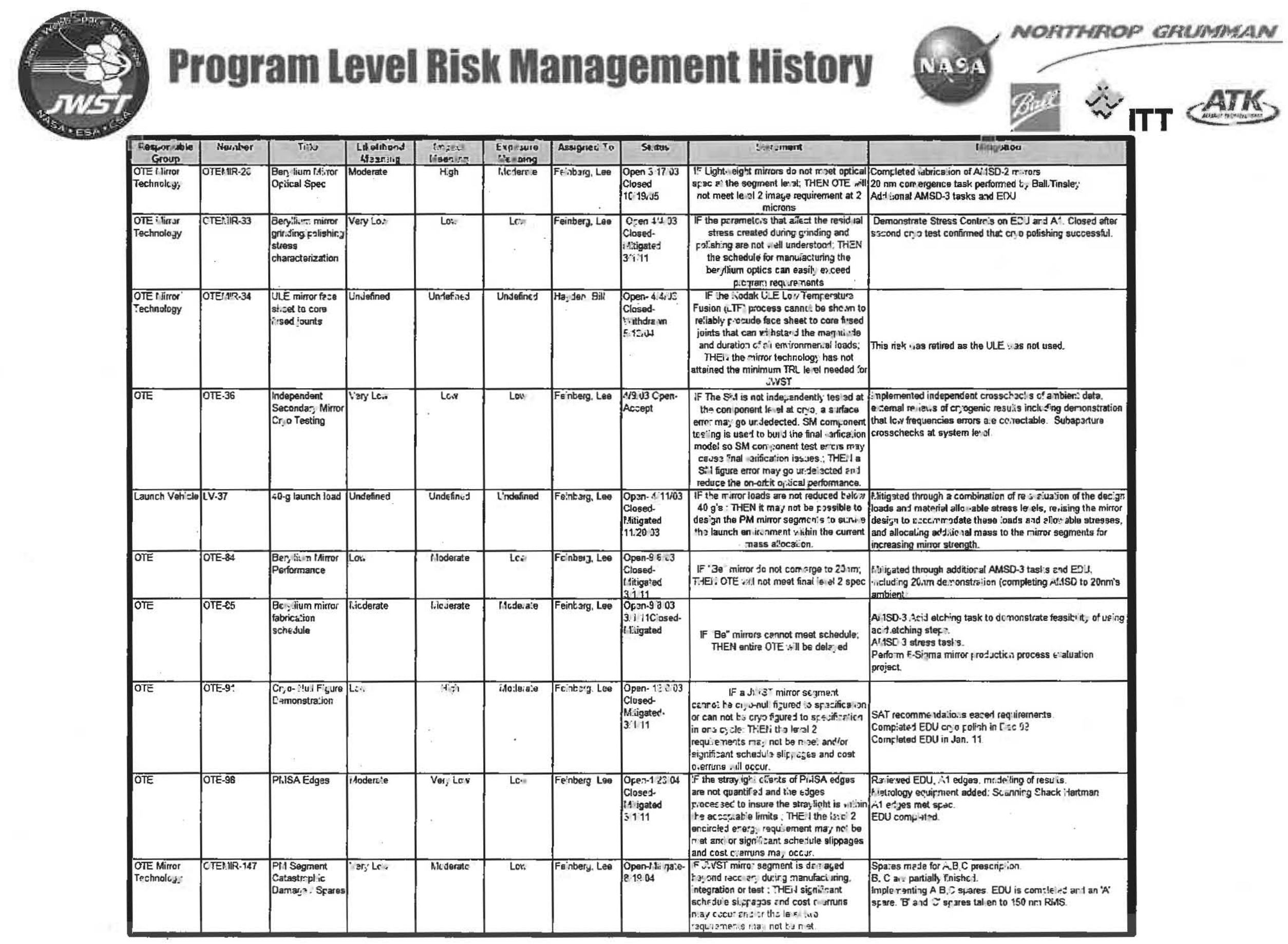




\section{Mirror Assembly Configurations}

Configuration 1

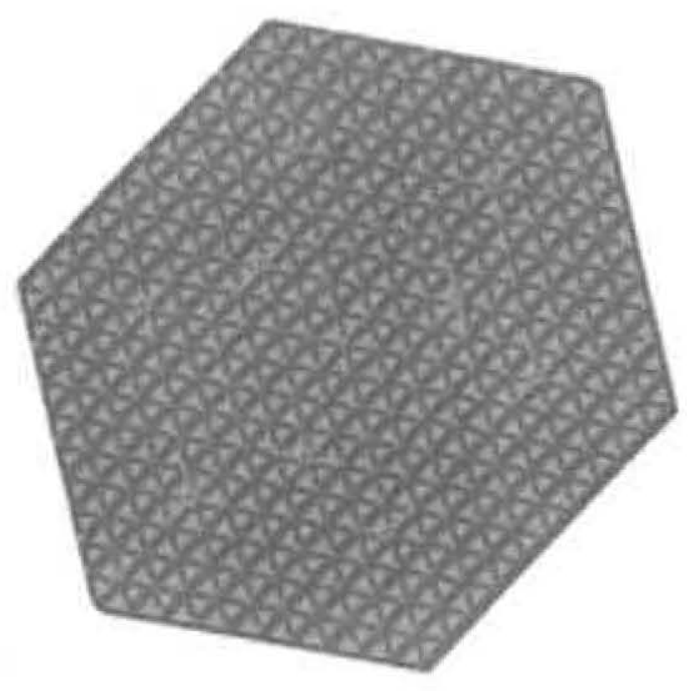

Mirror Substrate Only

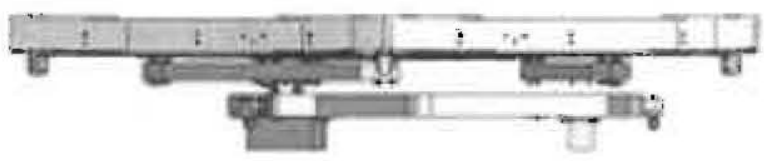

Configuration 2

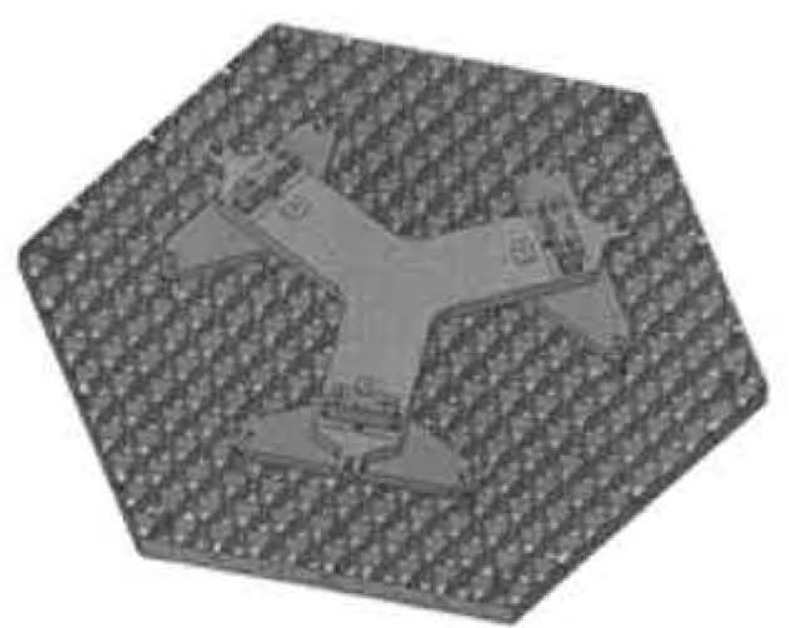

Mirror Substrate with Flexures, Whiffles and Surrogate Delta Frame
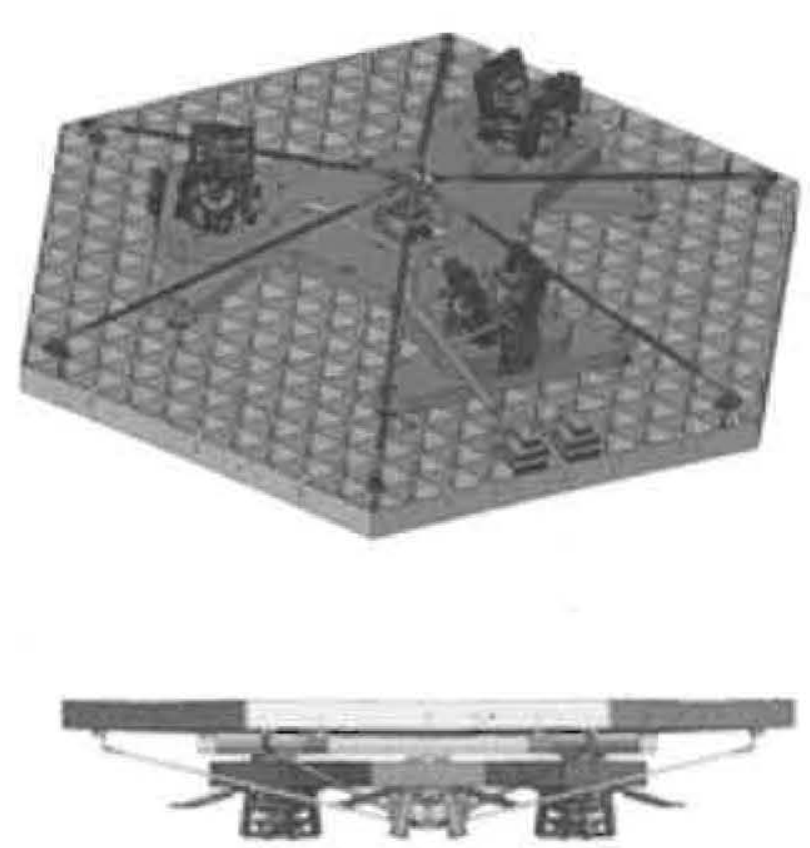

Fully Assembled PSMA with Hexapod Assembly and ROC Actuator 


\section{PMSA Processing Flow}
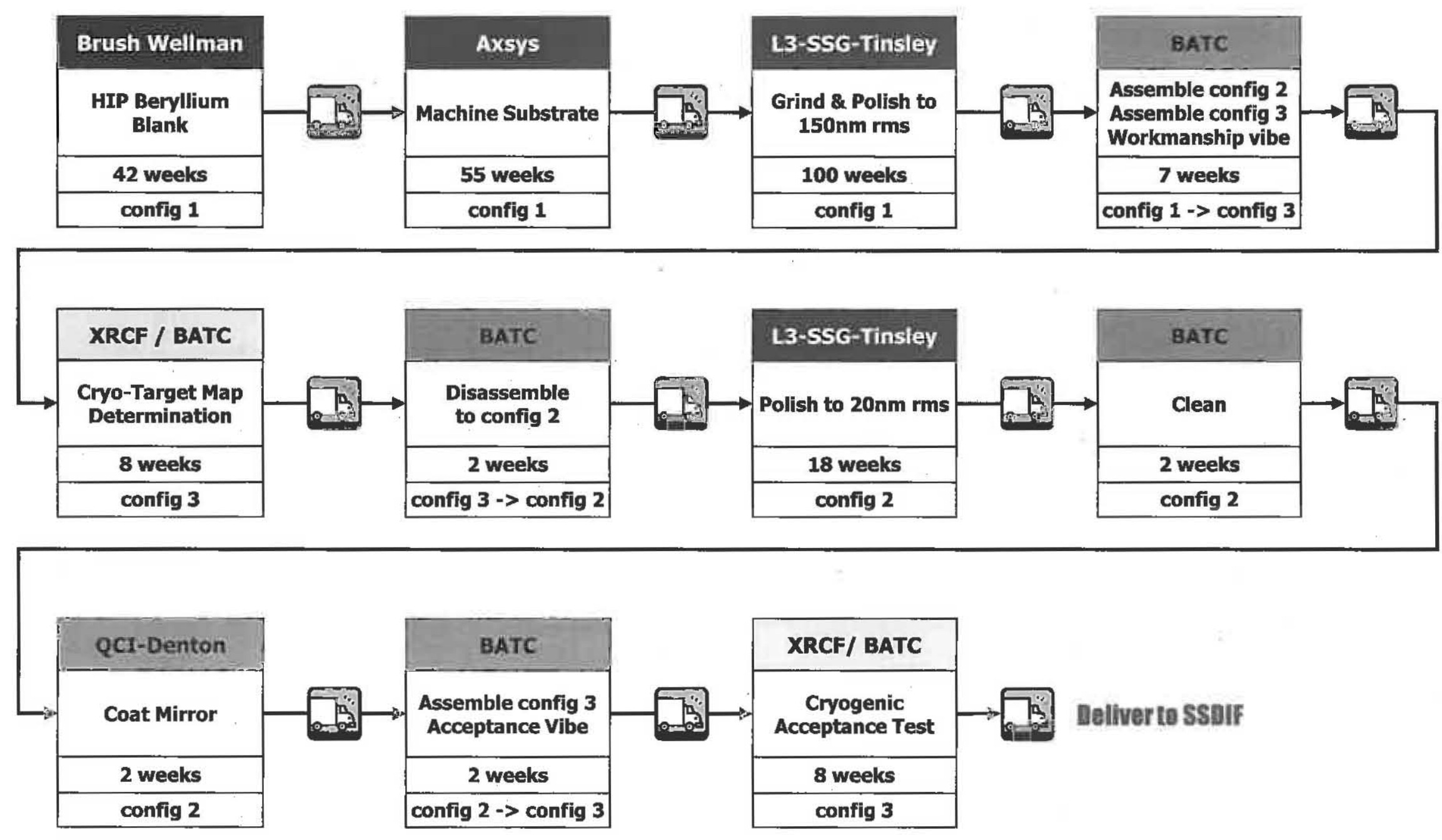


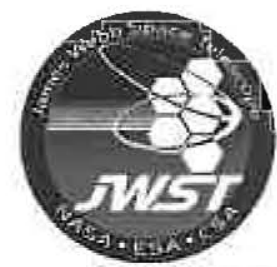

\section{Environmental Testing}
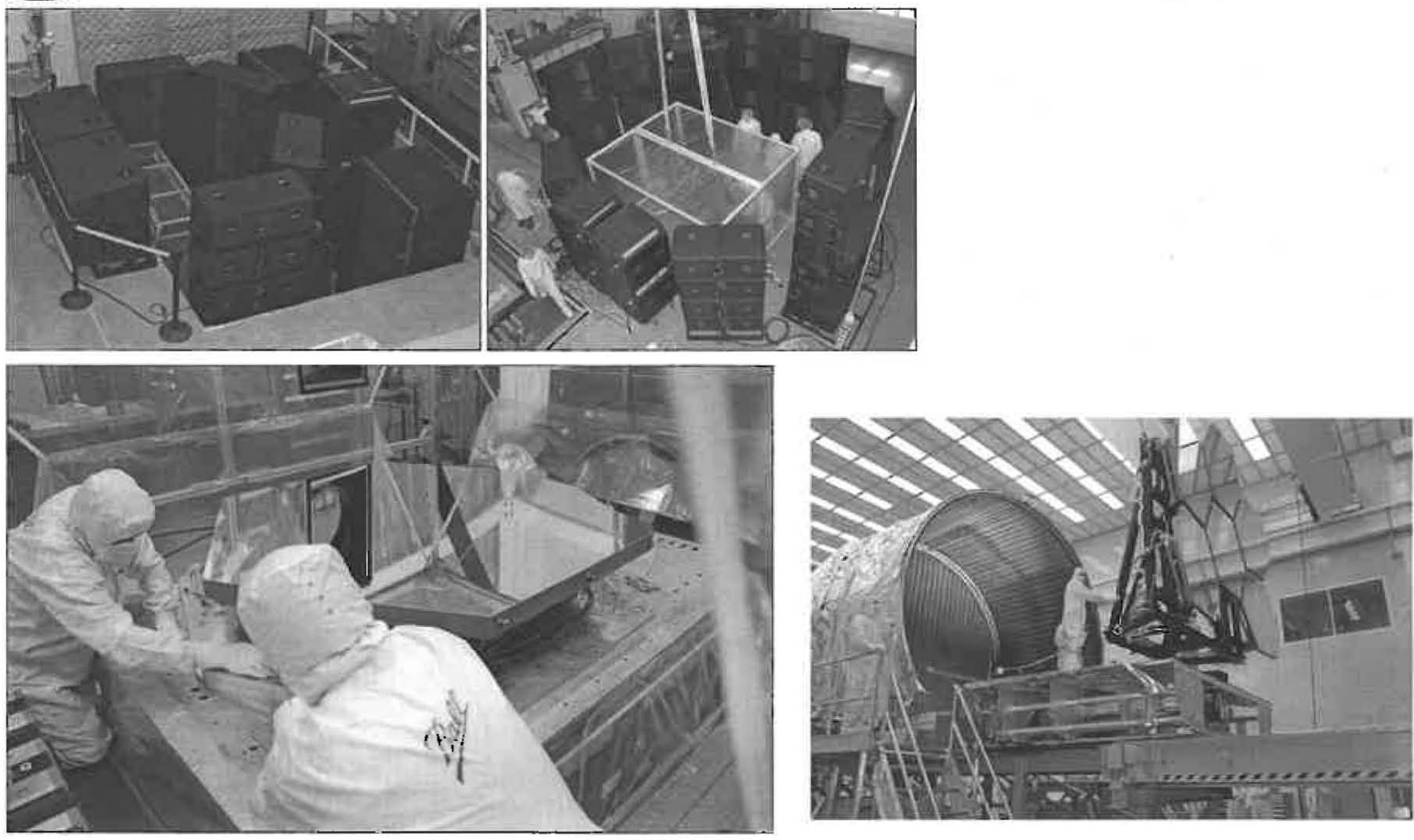


\section{Mirror Fabrication and Test Now Complete [As Run Schedule]}
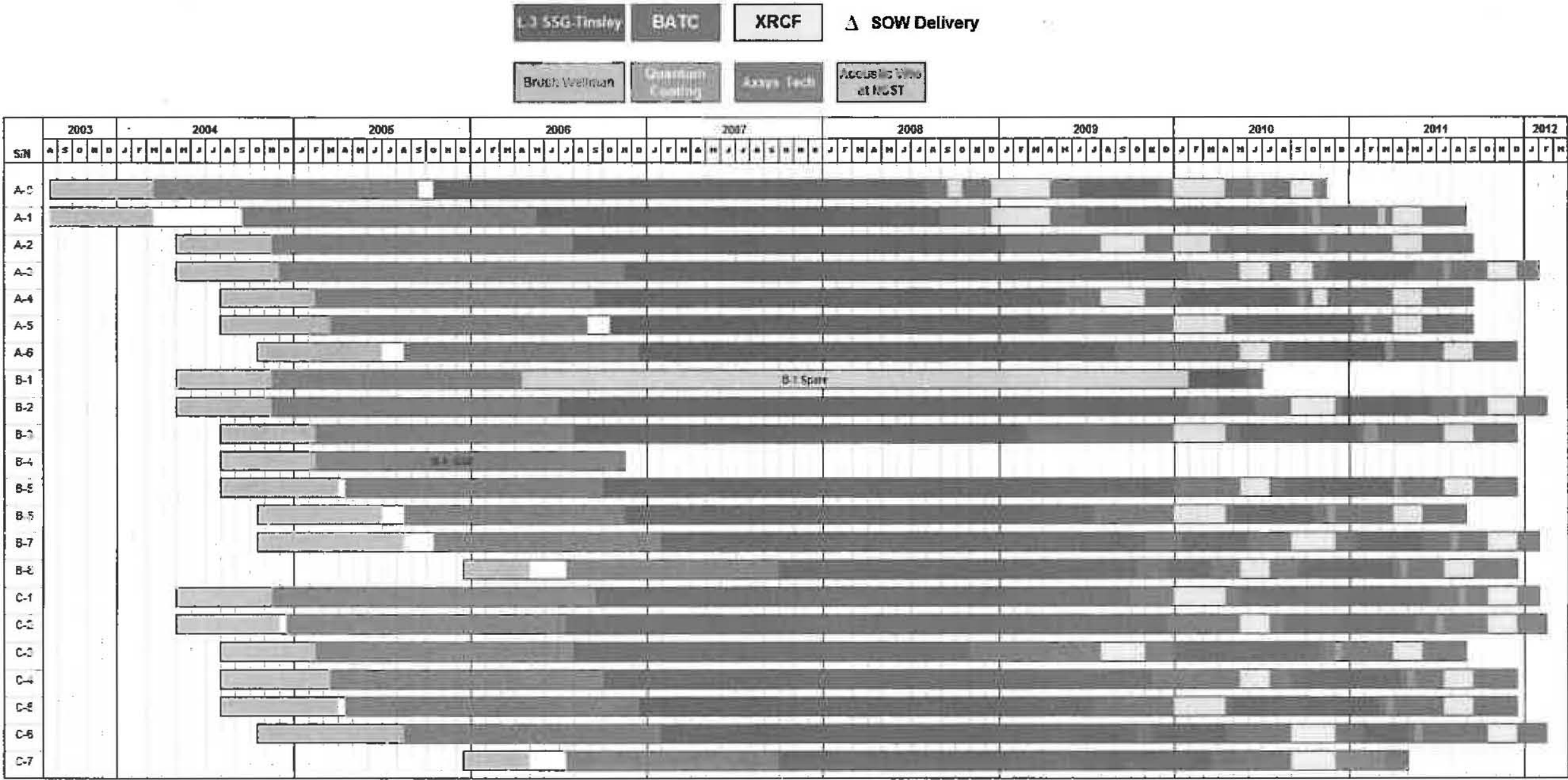


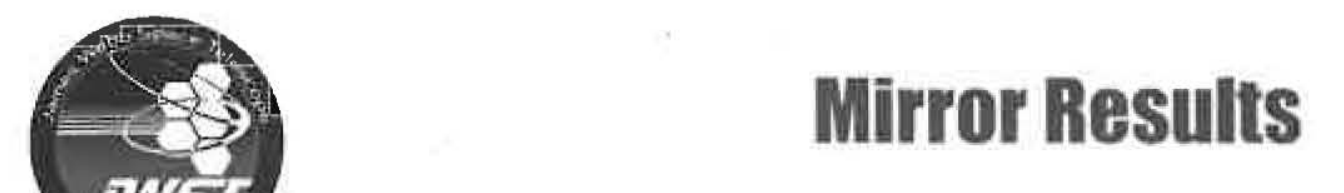

Aine $=5$ S

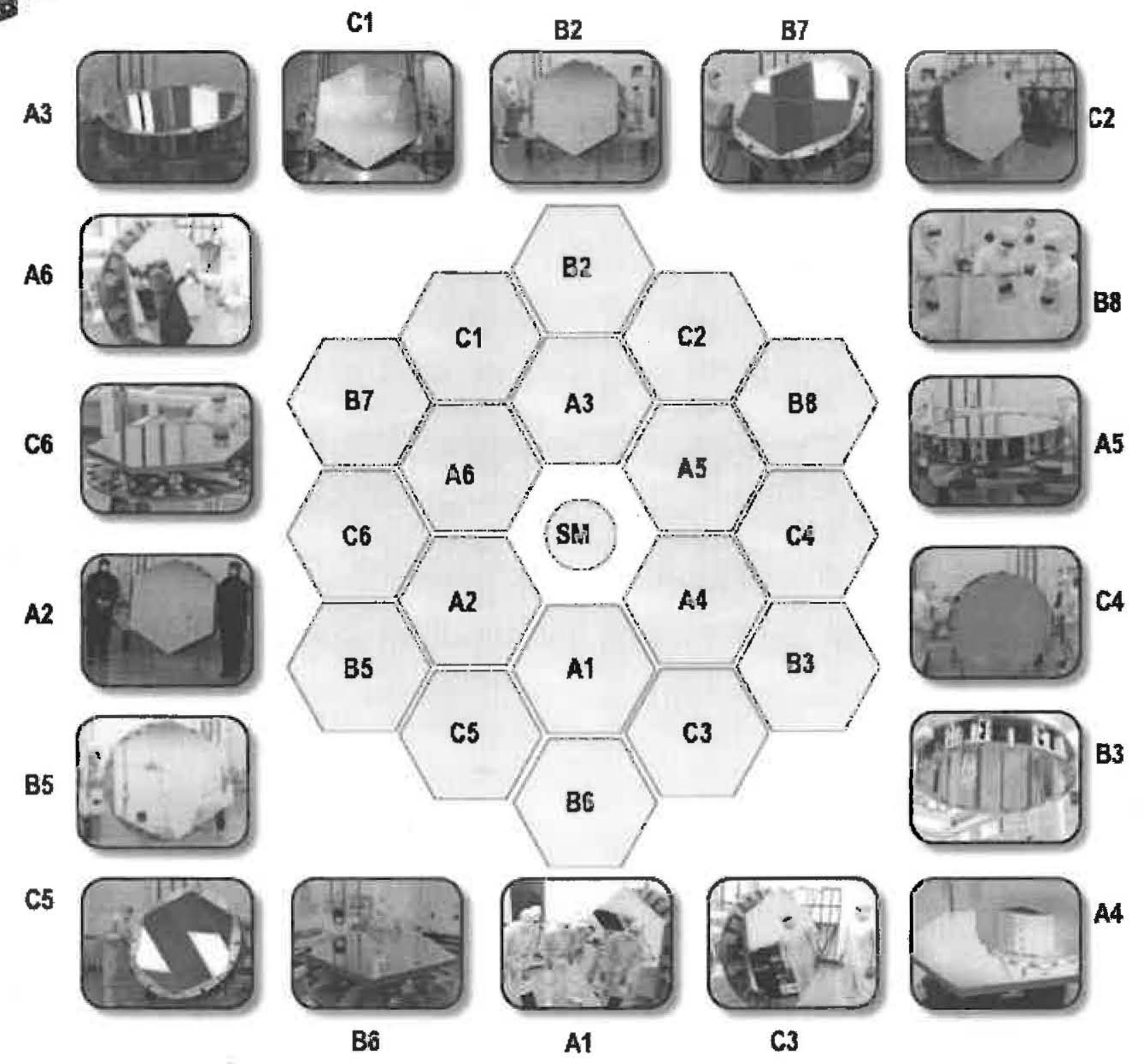

NORTHROP GAUMPAAN

Deg $Q$ ATK 


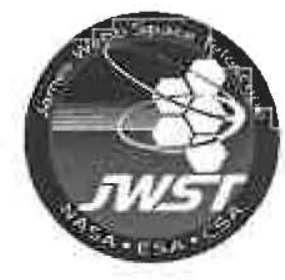

\section{JWST Mirrors Completed in 2011}

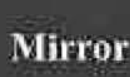

Measured

(iiii rins SED)

Uncertainty

(iin rus SFE)

Total
(iim russFE

Reg

Margin

(nm rus SFE) (um rms SFE)

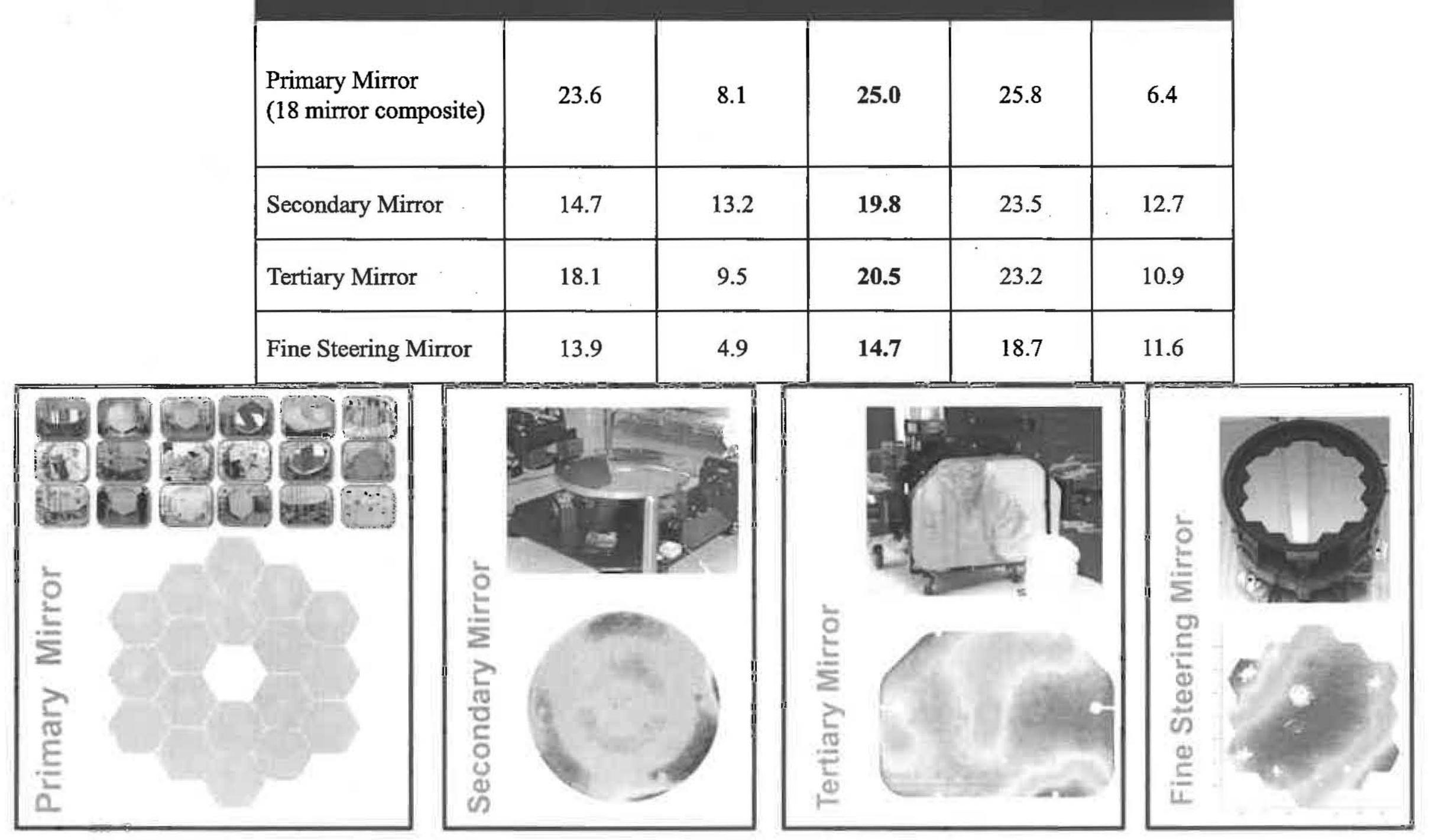




\section{Tinsley Results Summary [p.1]}

\begin{tabular}{|c|c|c|c|c|c|c|c|c|c|c|c|c|c|c|c|c|}
\hline $\begin{array}{c}\text { allocation } \\
\text { max } \\
\min \\
\mathrm{rms} \\
\mathrm{re} \\
\end{array}$ & Surface map & $\begin{array}{c}\text { SFE P-V } \\
\text { inm; } \\
- \\
957 \\
150 \\
634 \\
535 \\
\end{array}$ & $\begin{array}{c}\text { SFE ms } \\
\text { inm; } \\
23.1 \\
16.0 \\
8.05 \\
13.85 \\
12.5 \\
\end{array}$ & 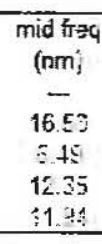 & $\begin{array}{c}\text { hi freq } \\
\left.(n n)^{\prime}\right) \\
9.5 \\
3.37 \\
4.00 \\
6.45 \\
6.34 \\
\end{array}$ & \begin{tabular}{|c|} 
surf ruf ms \\
$(n \mathrm{~nm})$ \\
4 \\
$3.5 \%$ \\
2.35 \\
3.25 \\
2.25 \\
\end{tabular} & $\begin{array}{c}\text { surf nof sd } \\
\text { inrin } \\
- \\
0.7 \\
0.2 \\
0.35 \\
0.33 \\
\end{array}$ & 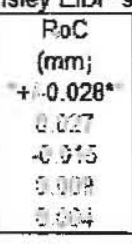 & $\begin{array}{l}\text { conic } \\
\text { constant } \\
++1-0.001^{*}\end{array}$ & 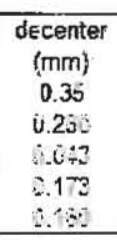 & $\begin{array}{c}\text { clocking } \\
\text { imrady } \\
0.35 \\
0.215 \\
-3.232 \\
0.110 \\
0.002 \\
\end{array}$ & 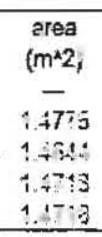 & $\begin{array}{c}\text { SFE stab } \\
\text { (nm: } \\
1: \\
1.4 \\
2.4 \\
3 . \% \\
\end{array}$ & $\begin{array}{c}\text { RoC stab } \\
\text { (mm! } \\
- \\
0 . j 25 \\
-0.031 \\
0.048 \\
0.320 \\
\end{array}$ & 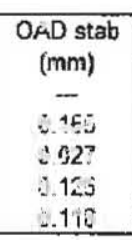 & $\begin{array}{l}\text { Ship date } \\
\text { from Tinsley } \\
3: 52010 \\
1: 232: 03\end{array}$ \\
\hline A1 & & 826.1 & 15.58 & 14.62 & 5.38 & 3.39 & 0.29 & $0.02 ?$ & 0.00022 & 0.153 & -0.232 & 1.4747 & -2.80 & 0.02 & 0.165 & $3: 9: 2010$ \\
\hline A2 & & 956.7 & 16.59 & 15.80 & $5.3 ?$ & 316 & 0.67 & 0.016 & 0.00022 & 0.043 & 0.042 & 1.474? & 3.54 & 0.05 & 0.151 & $12,1 / 2008$ \\
\hline A3 & & 349.5 & 1065 & 8.35 & 6.61 & 3.27 & 0.31 & 0.008 & 000022 & 0.210 & 0.021 & 1.4775 & 3.54 & -0.081 & 0.142 & $1: 20 \leq 310$ \\
\hline At & & 605.7 & 9.45 & 8.20 & 4.69 & 3.16 & 0.30 & 0.0038 & 0.00022 & 0.164 & -0.075 & 1.4747 & 4. 16 & 0.039 & 0.163 & 5.:2009 \\
\hline A5 & 10 & 125.8 & 15.81 & 17.6 & 5.07 & 3.60 & $0 .+2$ & 0.002 & 0.00022 & 0.80 & 0.040 & 1.4754 & 4.82 & 0.032 & 0.146 & $47: 2009$ \\
\hline AS & & 770 & 18.00 & 16.53 & ?.13 & 2.96 & 0.19 & 0.603 & 0.00022 & 0.210 & 0.210 & 1. .74 .5 & 2.88 & 0.080 & $0.12 \hat{\varepsilon}$ & 8:17,2009 \\
\hline 82 & & 540 & 14.08 & 10.50 & 9.37 & $3 . \varepsilon$ & 0.28 & -0.015 & $c .000: 2$ & 0.210 & 0.016 & 1.4747 & 3.12 & 0.022 & 0.133 & $1 / 9.2010$ \\
\hline B3 & & 321 & 8.65 & $\epsilon:$ & 5.72 & 3.33 & 0.43 & 0.003 & 0.00022 & 0.228 & -0.017 & $1.477 !$ & 4.86 & $0.00 \varepsilon$ & 0.160 & 6/24:2009 \\
\hline
\end{tabular}

\section{政}




\section{Tinsley Results Summary [p.2]}

\begin{tabular}{|c|c|c|c|c|c|c|c|c|c|c|c|c|c|c|c|c|}
\hline $\begin{array}{l}\text { allocation } \\
\max \\
\min \\
\mathrm{rms} \\
\mathrm{aie}\end{array}$ & Surface map & $\begin{array}{l}\text { SFE P-V } \\
\text { (nm) } \\
364 \\
36: \\
5: \\
35 \\
5\end{array}$ & $\begin{array}{c}\text { SFE ms } \\
(\mathrm{nm} ; \\
23.1 \\
1843 \\
23.3 \\
13.27 \\
13.57 \\
\end{array}$ & 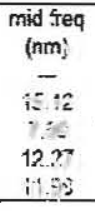 & 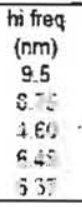 & \begin{tabular}{|c|} 
surf ruf rms \\
$m n m$, \\
4 \\
$2 \vdots$ \\
$2 \%$ \\
$3 \% n$ \\
3.8 \\
\end{tabular} & $\begin{array}{c}\text { surf ruf sd } \\
\text { (nm; } \\
- \\
7.45 \\
t .2 \\
0.22 \\
3.31 \\
\end{array}$ & $\begin{array}{c}\text { RoC } \\
\text { (mm) } \\
+-0.028^{*} \\
0.04 \\
0.05 \\
1.0 .02 \\
\end{array}$ & $\begin{array}{c}\text { conic } \\
\text { constent } \\
-0.001^{*}\end{array}$ & $\begin{array}{c}\text { decenter } \\
\text { (mm } \\
0.35 \\
0.215 \\
0.25 \\
0.15 r \\
133 \\
\end{array}$ & $\begin{array}{c}\text { clocking } \\
\text { (mred) } \\
0.35 \\
0213 \\
-0.11 .4 \\
114 \\
60.2 \\
\end{array}$ & 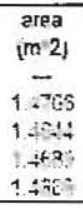 & $\begin{array}{c}\text { SFE stab } \\
\text { (nm) } \\
- \\
4.52 \\
1.54 \\
2.54 \\
3.75 \\
\end{array}$ & $\begin{array}{c}\text { RoC stab } \\
\text { (mm: } \\
-- \\
0.034 \\
0.054 \\
0.5: 5 \\
j .037 \\
\end{array}$ & $\begin{array}{c}\text { OAD stab } \\
(m m) \\
- \\
1 \\
02 \\
1.1 \\
C: 5 \\
\end{array}$ & 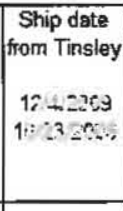 \\
\hline B5 & & 292 & 9.34 & 7,90 & 4.99 & 3.25 & 0.31 & $-0.0 c 3$ & 0.00022 & 0.092 & 0.017 & $1.4^{7} 48$ & 3.88 & 0.084 & 0.143 & 1232009 \\
\hline B6 & & 413 & 15.97 & 14.90 & 5.76 & 3.04 & 0.46 & 0.005 & 0.00022 & 0.087 & -0.013 & 1.4754 & 420 & 0.020 & 0.132 & $7,10,2009$ \\
\hline 87 & & 337 & 1284 & 11.2 & 6.28 & 3.31. & 0.32 & 0.006 & 0.00022 & 0.045 & 0.038 & 1. 4766 & 3.36 & 0,006 & 0.030 & 10.212009 \\
\hline B8 & & 864 & 13.80 & 12.30 & 6.25 & 3.24 & 0.35 & 0.001 & 0.00022 & 0.190 & .0 .037 & 1.4748 & 3.43 & 0.004 & 0.093 & 9:30;2009 \\
\hline c1 & & 670 & 11.08 & 8.69 & 6.87 & 3.33 & 0.25 & $-0.0 c 4$ & 0.00022 & 0.105 & -0.031 & 1. $46+6$ & 1.99 & 0.054 & 0.069 & 8182009 \\
\hline $\mathrm{C} 2$ & & $8 \leqslant 1$ & $16 .+6$ & 15.12 & 6.50 & 3.18 & 0.20 & $0.00 \mathrm{E}$ & 0.00422 & 0.215 & 0215 & 1.4646 & 2.84 & 0.071 & 0.121 & $12+2009$ \\
\hline 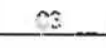 & & 274.8 & 14.55 & 13.80 & 4.60 & 3.47 & 0.35 & 0.006 & 0.00022 & $0.1 \subseteq E$ & 0.156 & 1.4652 & 1.8? & 0.053 & 0.107 & $1023,20 \mathrm{C} 8$ \\
\hline C4 & & 5.55 & 16.26 & 13.70 & 8.75 & 2.89 & 0.2 & $-0.0 \times 3$ & 0.00022 & $0.14 ?$ & -0.134 & 1.4644 & 4.61. & 0.011 & 0.130 & $10 ; 30.2069$ \\
\hline C5 & & 579 & 14.90 & 1370 & 587 & 3.39 & 0.38 & 0.002 & 0.07022 & $0.08 ?$ & -0.059 & 1.4644 & 804 & 0.004 & 0.075 & 625,2009 \\
\hline C6 & & 740 & 11.61 & 8.53 & 7.82 & 2.39 & 0.2 & 0.006 & 0.00022 & 0.210 & .0 .103 & 1. $\{E 44$ & 4.35 & 0.033 & $0.0 \varepsilon^{-7}$ & $10 / 2: 2009$ \\
\hline
\end{tabular}




\section{KRCF Testing Results}

\begin{tabular}{|c|c|c|c|c|c|c|c|c|c|c|c|c|c|c|c|c|c|c|c|c|}
\hline & $\begin{array}{l}\text { SFE fotal } \\
\text { measured } \\
\text { (nam mas; }\end{array}$ & 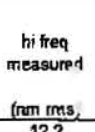 & $\begin{array}{l}\text { XRCF tot } \\
\text { rzssurved } \\
\text { iam mmsin }\end{array}$ & 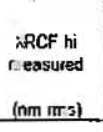 & 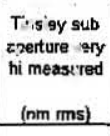 & $\begin{array}{c}\text { SFE metr og og: } \\
\text { unceftainty lot } \\
\text { (nmm ms. }\end{array}$ & \begin{tabular}{|c} 
SFE \\
mertology \\
uncertininty hi \\
(nnm nns) \\
\end{tabular} & $\begin{array}{l}\triangle R \text { of (nom) } \\
\text { (mmm }\end{array}$ & 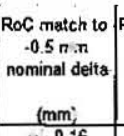 & 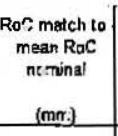 & 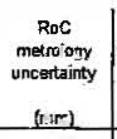 & 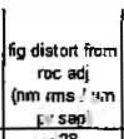 & 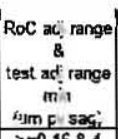 & 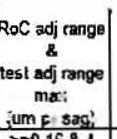 & 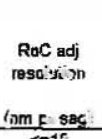 & 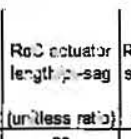 & 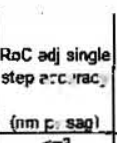 & 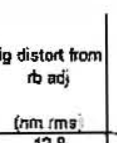 & $\begin{array}{l}\text { asio cistort } \\
\text { from mod } \\
\text { (ninm min) }\end{array}$ & $\begin{array}{l}\text { Ship da } 3 \text { fom } \\
\text { Tinsley }\end{array}$ \\
\hline $\begin{array}{l}\text { alictration } \\
\text { ma: }\end{array}$ & $\begin{array}{l}23.5 \\
1: 2\end{array}$ & $\begin{array}{l}122 \\
11=\end{array}$ & 40 & 11. & 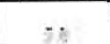 & t. & . & 1 & 0.04 & $\cdots$ & 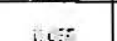 & 28 & & $>=0.1684$ & $k=16$ & $\mathrm{na}$ & $\Leftrightarrow=3$ & $\frac{12.8}{11.8}$ & & \\
\hline $\min$ & 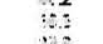 & \pm 1. & 1. & 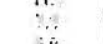 & $\because \because$ & $8:$ & 2.3 & 6 & 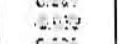 & $\because$ & 0.2 & at & $\therefore$ & 3. & $\therefore$ & & 1 & 9 & 195 & to 20 \\
\hline $\begin{array}{l}\text { mms } \\
\text { mean }\end{array}$ & $\therefore 4$ & $\subseteq 9$ & -10 & है & 3 & 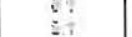 & 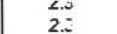 & $-5 \tau^{\circ}$ & 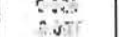 & iा & $\ldots$ & $2: \varepsilon$ & .13 & 4.6 & $\because 4$ & 33 & 1 & 11.3 & $2 \div 8$ & \\
\hline $\begin{array}{c}\text { s.u } \\
\text { cum }\end{array}$ & $\therefore$ & .4 & 7.3 & & 3 & 31 & in & $v \leqslant$ & $\therefore: 3$ & $0.2 \%$ & $\because 4$ & 1.2 & 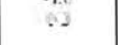 & 0.4 & $\therefore$ & 8 & 31 & if & 53 & \\
\hline A1 & 17.9 & 9.5 & 17.7 & 5.0 & 2.9 & 8.9 & 2.3 & -0.406 & $0.0+2$ & +047 & $c .085$ & 193 & -0.662 & 4.444 & 0.37 & 22.0 & 80 & a.s & 20.9 & $39: 2010$ \\
\hline$A^{n}$ & 222 & 11.2 & 21.9 & $\{2.7$ & 3.4 & 81 & 2.3 & -0.504 & -0.004 & $\therefore .003$ & 0.025 & 19.3 & $-1 . \leqslant 99$ & 4.355 & 0.37 & 21.2 & 0.05 & 10.2 & 19.6 & $12 \div 2000$ \\
\hline A3 & 21.8 & 12.3 & 21.0 & 10.8 & 5.8 & 8.0 & 2.3 & -0.507 & -0.007 & 0.000 & 0.063 & 19.4 & - .911 & 4.875 & 0.38 & 207 & 1.0? & 10.4 & 26.3 & $1 / 202010$ \\
\hline A4 & 17.1 & 8.2 & 16.8 & 75 & 3.2 & 8? & 2.3 & -0.520 & -0.020 & 0.013 & $0.10 \tilde{0}$ & 19.1 & -1.55? & 3906 & 0.37 & 220 & ( 13 & 10.8 & $26 ?$ & 56:2009 \\
\hline As & 16.5 & 10.1 & 15.7 & 8.8 & 5.0 & 80 & 2.3 & -0.599 & -0.039 & 0.032 & 0.085 & 19.2 & -1.455 & 4.229 & 0.38 & 21.1 & 0.08 & 10.6 & 31.1 & 4772009 \\
\hline s.5 & 44.2 & 12.5 & 44.0 & 11.7 & 4.5 & 8. & 23 & -0.483 & 0.017 & -.024 & 0.055 & 19.8 & .1.240 & +.025 & 0.35 & 2.5 & 0.05 & 10.0 & 30.9 & B.17:2009 \\
\hline 82 & 18.7 & 92 & 178 & 7.2 & 5.7 & 82 & 2.3 & -0.502 & -0.002 & -0.0275 & 0.084 & 21.1 & -7.888 & 5.170 & 0.40 & z..1 & 0.22 & 11.7 & 25.6 & 19,22010 \\
\hline B3 & 19.7 & 9.1 & $1: 2$ & 8.1 & 4.2 & $B_{2}$ & 2.3 & -0.524 & -0.024 & 0.017 & 0.054 & 226 & $-1: 31$ & 4.954 & 0.41 & 19.6 & 0.14 & 122 & 25.9 & Fi:2 2009 \\
\hline B5 & 16. & 9 & 18.0 & 8.1 & 3.9 & 8.2 & 22 & -0.493 & $0 . x^{2}$ & c.014 & $0.6=$ & 21.8 & -1.414 & $4.59 \mathrm{i}$ & 0.41 & 19.9 & $\cos$ & 11.9 & 22.0 & $12=2009$ \\
\hline B6 & 17.5 & 10.2 & $1>0$ & $\subseteq 4$ & 40 & 8.2 & 2.3 & -0.496 & 0.004 & f.011 & ovist & 21.8 & -1.76 & 4.319 & 0.41 & 19: & c.13 & 11.3 & wh & $710: 2009$ \\
\hline 87 & 22.6 & 8.9 & 222 & $\therefore 8$ & 4.3 & B.2 & 2.3 & .0 .52 & $-0.02^{2}$ & 0.020 & 0.084 & 21.8 & . J.Eं5 & 5.469 & 0.41 & ४१.9 & (1:1) & 12.8 & 361 & 10.21:2009 \\
\hline$B_{0}$ & 23.7 & 9.5 & 27.3 & 0.4 & 4.6 & 82 & 2.3 & -0.53 & -0.024 & 0.017 & $\cos 4$ & 220 & -1.637 & $\$ .698$ & 0.43 & $: 3.2$ & 0.13 & 13.3 & $2: 4$ & \$30.2009 \\
\hline c1 & 221 & 9 & $2: 5$ & $7 \because$ & 51 & 82 & 23 & $+52 C$ & .0720 & 0.013 & 0.082 & 21.9 & -1.263 & 4.895 & 0.0 & 19.6 & 033 & 11.2 & 30.2 & P'18 2009 \\
\hline$c_{2}$ & 20.1 & 87 & 19.5 & 21 & 5.0 & 8.2 & 2.3 & - 5531 & -0.031 & 0.024 & COĊ2 & 21.6 & .1 .155 & 4.57 & 0.20 & 3.6 & c.: & 12.1 & 33.4 & $12 \div 26 \mathrm{cs}$ \\
\hline c3 & 18.1 & 8.1 & 19.8 & 7.4 & 3.2 & 8.2 & 2.3 & C.A1S & 0.081 & eter: & Co:? & 21.5 & .1873 & $\therefore 611$ & 0.39 & 25: & L.0: & $1 \mathrm{ng}$ & 31 & 102520.8 \\
\hline c. & 39.5 & 12.3 & $3: 2$ & 11.2 & 5.0 & 8.2 & 2.3 & -0.491 & 0.203 & -0.015 & P.0ट2 & 20.3 & -1.199? & 4.E5\% & 0.11 & 23.1 & 1.22 & 11.2 & mi & $1 \mathrm{r}, 30.20,19$ \\
\hline$c s$ & 20.5 & 16.2 & $2 \geqslant 1$ & 9.3 & 4? & 8.2 & 2.3 & .0532 & .0 .032 & 2025 & 0.082 & 20.9 & $-1,755$ & 4.54.4. & 0.50 & 20.1 & 6.19 & 11.0 & 29.1 & $C=202009$ \\
\hline C6 & 23.9 & 11 & 23.3 & 8.4 & 5.4 & 8.2 & 23 & -0.532 & $-c .032$ & 0.025 & c.082 & 21.4 & -1.007 & 5.668 & 0.41 & $3:$ & 621 & 12.6 & 32.5 & $162=063$ \\
\hline
\end{tabular}




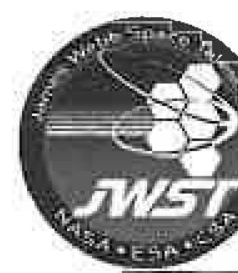

\section{The Team}

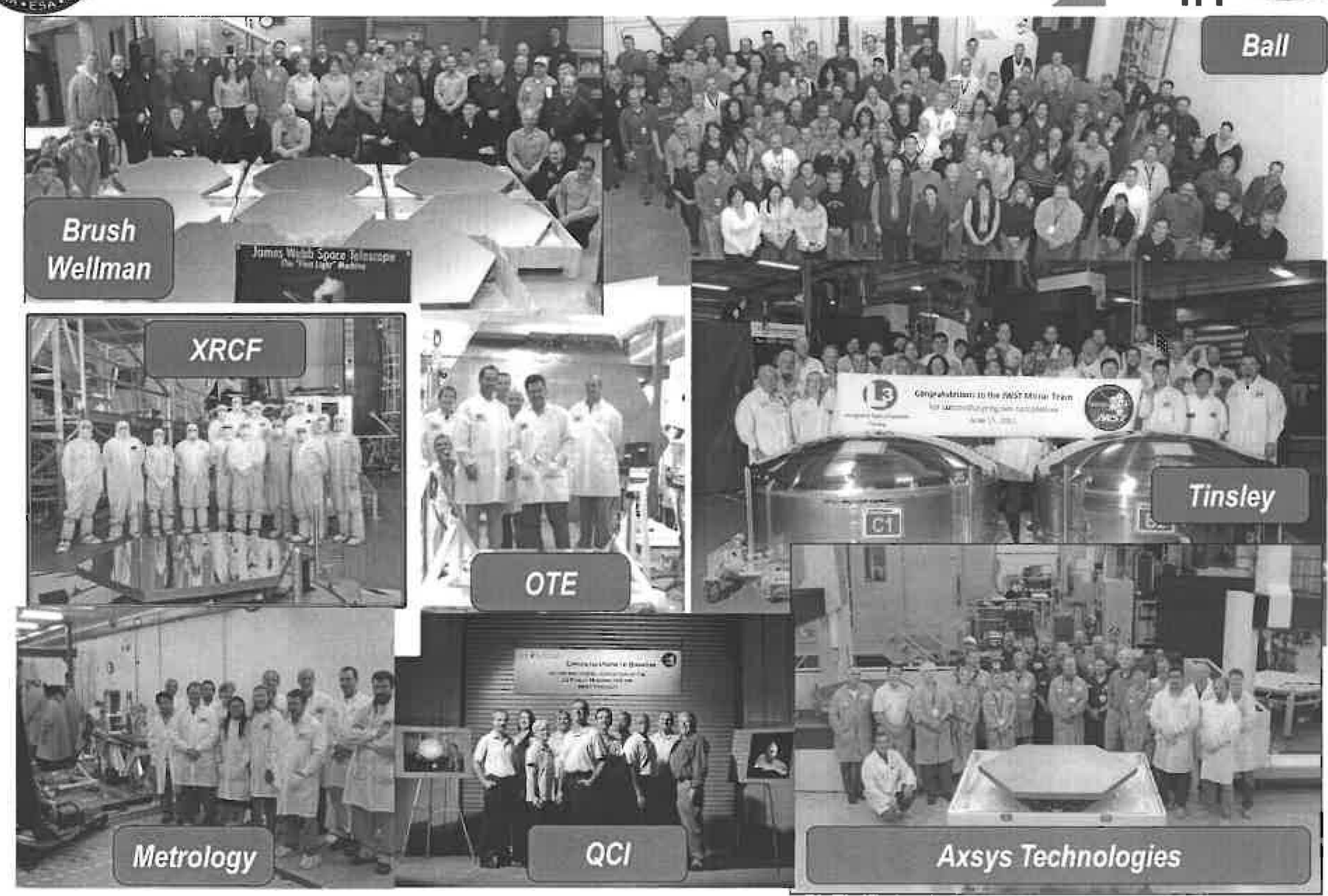




\section{Summary}

- In under a decade, 21 flight mirrors including the $>25$ square meters of lightweighted, cryogenic beryllium mirrors were developed

- The original technology effort benefitted from a collaboration between NASA and other government agencies

- The development effort was primarily a collaboration between NASA, Industry and Academia

- The mirrors meet their top level specifications

- We overcame many technical challenges

- Our focus now is on finishing the rest of the telescope and performing system level testing 